\title{
Small Towns Recovery and Valorisation. An Innovative Protocol to Evaluate the Efficacy of Project Initiatives
}

\author{
Emanuela D'Andria, Pierfrancesco Fiore (D) and Antonio Nesticò *(D) \\ Department of Civil Engineering, University of Salerno, 84084 Fisciano, Italy; emdandria@unisa.it (E.D.); \\ pfiore@unisa.it (P.F.) \\ * Correspondence: anestico@unisa.it; Tel.: +39-089-964318
}

Citation: D'Andria, E.; Fiore, P.; Nesticò, A. Small Towns Recovery and Valorisation. An Innovative Protocol to Evaluate the Efficacy of Project Initiatives. Sustainability 2021, 131, 311. https://doi.org/10.3390/ su131810311

Academic Editors:

Valentina Antoniucci and

Giuliano Marella

Received: 9 August 2021

Accepted: 7 September 2021

Published: 15 September 2021

Publisher's Note: MDPI stays neutral with regard to jurisdictional claims in published maps and institutional affiliations.

Copyright: (c) 2021 by the authors. Licensee MDPI, Basel, Switzerland. This article is an open access article distributed under the terms and conditions of the Creative Commons Attribution (CC BY) license (https:// creativecommons.org/licenses/by/ $4.0 /)$.

\begin{abstract}
In many Countries, the depopulation of small towns is a significant phenomenon, which is causing the disappearance of a vast material and immaterial heritage, the beating heart of national identities. However, in recent years, with the environmental and metropolitan crisis, a gradual change of trend is taking place in which small towns play a crucial role in rebuilding the city-countryside relationship. The sustainable development of territories is possible, but in order to achieve it, it is essential to reverse the gaze and consider small municipalities as the main driving force for a radical change. Nevertheless, too often administrations are inadequate in dealing with the complexity of small realities, defining strategies and funding projects that are inconsistent with the real and varied local needs. This work deals with the issue of the recovery and valorisation of small towns through multi-criteria analysis schemes able to capture not only the specific characteristics of the small municipality, but also its relations with the territory and with neighbouring medium/large cities or other surrounding small towns (city-villages network or small municipalities network), also with reference to the multiple infrastructural components. The aim was to identify the critical points of intervention actions and to effectively address future investments. The idea was to propose a technical-economic evaluation protocol structured on social, economic, environmental, and historicarchitectural components. The study of the criteria, divided into several sub-criteria, led to the proposal of innovative datasets of evaluation indicators. The model was applied to a case study. The results showed the validity of the investigation protocol, which can be an important tool for prioritising the interventions to be implemented, thus optimising the processes of resources allocation-both public and private-according to the principles of sustainable development, with relevant effects in terms of economic policy.
\end{abstract}

Keywords: small towns; recovery and valorisation; sustainable development; multi-criteria evaluation

\section{Introduction}

Small town depopulation is a widespread phenomenon that involves many countries in the world. However, in the last decade, something has been changing. As the environmental crisis progresses and the city-countryside relationship is gradually torn apart, there is a growing awareness about the importance of rediscovering inland urban realities [1]. Added to this, the current health emergency testifies to the urgent need to change modern lifestyles.

In this scenario, repopulating small towns can represent a concrete chance for the sustainable development of territories. The aim is to rebuild a dialogue between man and nature, recover local and national identities, encourage urban decongestion, and reduce land consumption: "for the first time these territories [are] beginning to be seen not only as a problem, but also as an opportunity" [2] (p. 5).

It is obvious, therefore, that the enhancement of small towns is an increasingly discussed topic and many international initiatives are underway. In this regard, it is important to highlight the role of the European Network for Rural Development (ENRD), which supports and disseminates rural development programmes, sharing information, best 
practices, and knowledge on the valorisation of inland areas and small towns. Among the ENRD projects, the one on Smart Villages is significant: it aims at overcoming service and employment deficits through the use of digital technologies and new forms of collaboration between different stakeholders (small municipalities, local actors, authorities, farmers, craftsmen, etc.) [3-5].

Some recent ESPON studies are also relevant, such as Small and medium sized towns in their functional territorial context [6]. This study investigated the role and relational characteristics of small and medium-sized towns with neighbouring cities, analysing their development potential in the light of the social, economic, institutional, environmental, and cultural issues of their territorial contexts.

With regard to the link between small towns and rural areas, of particular interest is the EU project, called H2020 ROBUST (Rural-Urban Outlooks: Unlocking Synergies), which identifies, analyses, supports, and strengthens policies and governance systems aimed at encouraging mutually beneficial relationships in the rural-periurban-urban axis.

Furthermore, the European project ESPON ESCAPE (European Shrinking Rural Areas: Challenges, Actions and Perspectives for Territorial Governance) addresses the issue of rural depopulation, outlining its causes and consequences, with the purpose of proposing integrated strategies and actions based on the opportunities offered by these territories [7].

The Global Ecovillage Network (GEN) is a worldwide association which, through the Ecovillage model, promotes ecological and shared lifestyles [8,9]. To date, there are approximately 2000 communities in the United States, 250 in Great Britain and Ireland, 100 in Germany, 33 in France, 13 in the Netherlands, 30 in Scandinavia, and 23 in both Spain and Portugal [10].

In addition, the joint goal of many countries is to valorise the small towns in order to rebuild a link between the metropolises and the more inland territories.

In this respect, a relevant example is France, which in 2015 adopted The city-countrysid e reciprocity agreements aimed at promoting inter-municipal partnerships to encourage cooperation between large, small, and medium-sized towns, villages, and rural areas. The intention is to reduce the economic and social gaps between the different parts, strengthening those most disadvantaged.

Still in France, the Plan Nos ruralités was drawn up by the new Rural Interministerial Committee in order to reorganise "the various national and local strategies, starting from the city-villages (intermediate Municipalities with a population of less than 10,000 inhabitants) and then extending to rural areas" [11] (p. 11). The Plan brought funds to carry out experimental valorisation programmes in 54 carefully selected small Municipalities.

Spain is probably the European Country that is most affected by the depopulation of its inland areas. In fact, the area surrounding the region of Madrid has just over seven million inhabitants in an area of $270,000 \mathrm{~km}^{2}$. As data from the National Statistical Institute testify, the 'empty Spain' [12] lost 61,684 inhabitants between 2017 and 2018, registering only $15 \%$ of the population living in half of the national territory [13]. In order to address this problem, the Programa Experimental de Recuperaciòn y Utilizaciòn Educativa de Pueblos Abandonados was set up in 1984, with the aim of revitalising small towns through cultural and educational projects. The activities of the Nuevos Senderos association, which selects job offers in rural areas and proposes them, with appropriate training, to immigrant families, are also relevant. A similar initiative has been taken by Ireland with Rural Resettlement Ireland (RRI), which provides free services to anyone who wants to move to the countryside [13].

Germany, on the other hand, has taken a different path, choosing to invest in renewable energy production for the enhancement of small municipalities. With this aim, the Bioenergy Villages strategy was born and currently involves 120 small towns where farmers and local cooperatives manage, produce, and distribute sustainable energy [13].

In Italy, a significant step forward has been taken by the Strategia Nazionale per le Aree Interne (SNAI). The Strategia has mapped marginal territories on the basis of the travel time needed to reach the pole-cities. The goal is to promote the development of 
these places by upgrading basic services (mobility, health, education). For the first time, a geography of "shrinkage" on a national scale has been given, which has undoubtedly ignited the debate on the future of inland areas and the role they could play today in rethinking the country's territorial organisation [14]. This has led to the development of numerous studies on the subject. For example, those carried out by the Associazione Riabitare l'Italia, which examines not only the causes of demographic decline, closely linked to historical and economic trends, but also the projects and policies in progress, providing a constantly updated overview [2]. The Associazione Nazionale Borghi del Respiro (National Association of Breathing Villages) aims to promote human health through safe lifestyles that combine respect for nature and the reduction of land consumption. In this context, the recovery of small towns plays a key role, as it offers the possibility of living in unpolluted places, practising outdoor, leisure, and socio-cultural activities.

In addition, there are also research projects carried out by universities and public institutions. Among these, of particular interest is Riabitare i Paesi. Strategie Operative per la Valorizzazione e la Resilienza delle Aree Interne (RI.P.R.O.VA.RE), recently funded by the Ministry of the Environment and Land and Sea Protection. This project, which involves three Italian universities (University of Campania 'Luigi Vanvitelli', University of Salerno, University of Basilicata), proposes a reflection on the classification and perimeter criteria of inland areas, as well as on the tools useful to assess and strengthen their resilience. The purpose is to elaborate possible development strategies aimed at combining the improvement of basic services, the mitigation of risks, and the enhancement of local resources.

Mention should also be given to the actions of organisations such as I Borghi più belli d'Italia (Italy's Most Beautiful Villages) or the Associazione Borghi Autentici (Association of Authentic Villages), which promote local beauty through an information network aimed at involving and sensitising communities on the issues of abandonment and depopulation. There are also those carried out by I Borghi della lettura (The Reading Villages), which assign culture a key role in promoting the knowledge of small towns. In addition, these actions are flanked by other intervention strategies. It is useful to mention the "Alberghi Diffusi", the "Health Villages", the "Artists' Villages", and the "Music Villages" [15-17]. In this context, it is necessary to underline that the above-mentioned strategies are addressed to municipalities whose resident population does not exceed 5000 inhabitants or whose establishment was the result of the merger of several municipalities each with a population up to 5000 inhabitants. This threshold, established by Law No 158/2017 (Measures for the support and enhancement of small municipalities, as well as provisions for the redevelopment and recovery of the historic centres of the same municipalities), defines the Italian 'small town'. Such a stringent limit does not reflect the cultural, economic, environmental, and historical complexity of a small town, thus risking the exclusion from funding of a large number of small municipalities which, despite having a higher population, are experiencing a strong and constant demographic decline.

However, intervening in small towns is a complex matter: "it is [...] a question of carrying out assessments [...] which allow problems and resources to be highlighted so that policies can then be drawn up, with a view to integrated planning" [18] (p. 77). In fact, the strategies adopted have not always achieved the desired outcomes. The reasons for this failure are to be found in the mostly punctual approach of the actions, which are the result of 'top-down' wills, unrelated to the real needs of the places. In addition, social, economic, environmental, and cultural issues are usually neglected and administrations are generally unprepared to deal with the multiple factors that characterise small realities.

There is a need to take action not just on building reuse, but also on environmental and landscape protection, as well as on social cohesion and infrastructure rehabilitation. Thus, it is evident that the revitalisation of small municipalities is feasible with a view to the territories' sustainable development, as there is a clear need to take into account social, economic, environmental, and cultural issues. Consequently, any project should necessarily be guided by the sustainability principles. In the light of the above, it is evident that there 
is the necessity to develop operational tools that combine multiple factors and that guide local administrations and experts in selecting the most effective valorisation interventions to be implemented in a small municipality. This selection must be carried out considering several assessment criteria: social, economic, environmental, and historic-architectural. This can be achieved by using multi-criteria analysis models (MCDA).

The multi-criteria analysis helps the decision-maker in solving complex problems that require the formulation of convenience judgments on numerous investment alternatives in the light of multiple and heterogeneous parameters $[19,20]$. The multi-criteria methods are largely used in different fields, from construction and project management to quality management, and from soft computing to sustainability and energy-environmental [19,21-30]. The widespread use proves their remarkable flexibility, which is translated into the ability to deal with the variability of existing situations, showing "a [...] use versatility especially in reference to questions characterised by the lack of univocity that are expressed in the proposal of a set of solutions usually [marked] by the presence of antagonistic interests" [29] (p. 11).

With these considerations, this paper addressed the issue of valorising small towns in accordance with the principles of sustainable development, i.e., considering together social, economic, environmental, and historic-architectural aspects. These questions do not refer exclusively to the small municipality, but are always read on a broader scale in which the infrastructural, social, and cultural fabric of the whole reference territory is examined, as well as the spatial relations between the poles-cities and the small towns.

\section{Aim of the Paper}

The work aimed to characterise a multi-criteria analysis model for the technicaleconomic assessment of strategies for the recovery and valorisation of small towns. Based on the Analytic Hierarchy Process (AHP) logic, the model proposes to detect the criticalities of the intervention actions and to compare different project ideas in a rational way in order to optimise the allocation processes of both public and private resources.

In particular, the model's structure is made up of evaluation criteria, sub-criteria, and indicators, organised in new datasets available to the operators: the social, economic, environmental, and historic-architectural components of the small town outline the analysis criteria, further broken down into 15 sub-criteria; each sub-criteria is associated with one or more evaluation indicators, collated from the literature and also integrated with specifically defined indices.

The criteria and sub-criteria panel and the datasets of evaluation indicators are the innovative elements of the research.

The paper is structured in the following sections: reference materials and methods; general structure of the investigation protocol; application to a case study; exposition of results and discussion; conclusions.

\section{Materials and Methods}

In view of the different tangible and intangible elements that distinguish the small towns, and considering the need to carry out organic programmed interventions, it is useful to prepare technical-economic tools aimed at selecting effective recovery and valorisation strategies. The reference criteria must be social, economic, environmental, and cultural, in accordance with the principles of sustainable development. These principles lead towards economic growth without forgetting the objectives of reducing poverty, promoting social solidarity, supporting policies aimed at strengthening the sense of community, and protecting the environment from harmful human activities: the environmental goal is to maintain the reproducibility of natural resources, guaranteeing their quality and protection; the social one intends to invest in human well-being, starting from the concepts of equity and equality; and the economic one prefigures the increase of employment opportunities [31].

In line with the principles of sustainable development, investing in the enhancement of small towns favours the efficient use of resources, limited land consumption, and the 
preservation of a vast tangible and intangible heritage: “The villages recovery [should not be understood] only and necessarily as a maintenance and restoring operation [of the pre-existences] [...], but it means going back to inhabiting the territory to re-establish a link with nature [...]. From this perspective, the memory of people and buildings is fundamental in order not to lose a cultural and knowledge heritage indissolubly bound to the artificial and natural environment [...]. Keeping the villages alive with their houses and their people means not losing [the] traditions" [14] (pp. 13,14) from which the countries can restart. Moreover, the regeneration of these places guarantees social, economic, environmental, and cultural dynamics in line with the goals of the 2030 Agenda: good health and well-being (goal 3), quality education (goal 4), employment (goals 8, 9), reduced inequalities (goal 10), and sustainable cities and communities (goal 11) [32].

The study topics must carefully consider the peculiarities of small towns.

Although it is appropriate to remember that "each village represents a history of its own, linked to its traditions, its conformation, its relationship with the territory but also to its current conditions and its potential for transformation" [14] (p. 15), it seems reasonable to group together some generally recurring characteristics. As reported in the literature $[2,13,14,17,18,33]$, small municipalities are usually located in disadvantaged areas, far from the bigger cities, and are marked by inadequate infrastructure and an ineffective basic service system. These conditions lead to their social, economic, and cultural isolation. However, while the gradual depopulation of these areas has caused their abandonment, it has also favoured the preservation of the original urban layout, as well as the typologicalconstructive features of the architectural artefacts. The strength of the genius loci is still visible in the strong relationship with the landscape and in the productive vocations of the neighbouring territorial contexts [34]. All these prerogatives can be synthetically translated into specific evaluation criteria and sub-criteria organised according to the hierarchical structure of the Analytic Hierarchy Process (AHP). Compared with other multi-criteria methods, the AHP allows:

- Breaking down decision problems according to a multi-level organisation (goal, criteria, sub-criteria, possible alternatives);

- Comparing quantitative and qualitative data;

- Managing and evaluating criteria, sub-criteria, and indicators;

- Consciously planning the actions to be implemented $[29,35,36]$.

In the evaluation process, each element at the same level is compared in pairs with each element at the higher level. Judgments are expressed according to Saaty's fundamental scale, in which: 1 expresses same importance between two elements perceived to be equally relevant; 3 indicates moderate importance, i.e., the evaluation is moderately in favour of one element compared to another; 5 indicates strong importance, the assessment is highly in favour of one item compared with another; 7 very strong importance, the assessment is even more strongly in favour of one element over another; 9 extreme importance, the assessment is extremely in favour of one element over another; and 2, 4, 6, and 8 give intermediate values between two evaluations [36].

The literature on the tangible and intangible components that distinguish small towns, the principles of sustainable development and the corresponding approaches for the multi-criteria analysis of villages' recovery and valorisation projects, as well as the Analytic Hierarchy Process' logical structure provide reference materials and methods for the research.

\section{Interventions for the Recovery and Valorisation of Small Towns. An Innovative Evaluation Protocol}

In the light of the above, the need to implement actions for the recovery and valorisation of small towns clashes with the difficulty of resolving complex and closely related issues: the territory's economic growth, which is essential to give future generations prospects of stability; the protection of the natural and built environment, which is more 
and more important in a sustainable development perspective; and the respect of local cultural and social traditions, a heritage that must certainly be safeguarded.

It immediately follows that any project must be assessed from a technical and economic point of view in the light of several criteria, which must consider the peculiarities (the "invariants") of the small towns that are to be recovered and enhanced. Each criteria then needs to be broken down into its many constituent elements, the sub-criteria. At this point, it is required to: (a) identify appropriate evaluation indicators, each able to express the capacity of the initiative to pursue the objective according to the corresponding criteria; and (b) assign the right weight to individual judgements, depending on the economic policy aims of the decision-maker.

Based on the above-mentioned logical sequence of phases, evaluation model shown in Table 1 was formulated, which is a useful reference for a comprehensive analysis of the criticalities and potentials of the strategies aimed at recovering and valorising small municipalities.

Table 1. The 5 steps for the analysis model characterisation.

\begin{tabular}{cc}
\hline & MODEL CHARACTERISATION \\
\hline Step 1 & Definition of evaluation CRITERIA \\
\hline Step 2 & Analysis of the small town' INVARIANTS \\
\hline Step 3 & Definition of SUB-CRITERIA \\
\hline Step 4 & Construction of the evaluation INDICATORS datasets \\
\hline Step 5 & WEIGHT assignment \\
\hline
\end{tabular}

It is a sequence of five steps which outline a real operational tool for examining intervention projects for villages. Each step is illustrated in detail in the following subparagraphs: criteria, invariants, sub-criteria, evaluation indicators, and weight assignment.

\subsection{The Evaluation Criteria}

The definition of criteria is carried out in the light of the sustainable development different components (social, economic, and environmental) and according to the relevance of the cultural dimension in the recovery and valorisation strategies for small towns.

In fact, the technical and economic evaluation of the interventions poses issues: socioanthropological, related to local traditions, to the strong sense of belonging to the places, to the human and cultural background of the communities; economic, on the strengthening of infrastructure systems and the productive fabric of the territory; environmental, with reference to the quality of air, water, and soil, and the protection of fauna and flora; and cultural, because of the need to properly consider the great material heritage of small municipalities, including churches, historical palaces, and other buildings of particular value and interest that significantly contribute to delineate the charm, identity, and memory of 'marginal areas' [37].

From these considerations, it is clear that any regeneration action must necessarily consider this great potential, safeguarding and preserving it. Thus, any evaluation cannot disregard to consider:

- Social criteria,

- Economic criteria,

- Environmental criteria,

- Historic-architectural criteria.

\subsection{The Small Town's Invariants}

The second step of the study protocol consists of analysing the small town's 'invariants', i.e., the recurring features [38].

The small municipalities have a wide variety of oral, gastronomic, and religious traditions that enrich the identity profile of places, including issues related to local history and culture. In addition to this, there is the presence of a huge valuable material heritage, 
which can be found in the quality of the existing buildings, using traditional techniques and specific typological-constructive features. Spontaneous architectures answer to the climatic and morphological conditions of the territory in which they are located, offering a concrete solution to the most urgent housing needs. Moreover, the original urban layout is generally still readable, being marked by a limited and compact built fabric, efficiently organised and easily accessible in all its parts.

The small towns are characterised by a rationalised, productive organisation, which promotes air and water quality as well as functional land use.

On the other hand, in inland areas there is a widespread shortage of infrastructure (parking areas, roads, railways, etc.), accompanied by a deficiency of basic services, including health care, schools, and groceries. These factors strongly influence the trend of demographic decline in small municipalities, which experience a constant state of uncertainty and abandonment.

Thus, the analysis of the sector's literature [13-15,39-42] makes it possible to identify 11 specific characteristics-the invariants-of the small towns:

- Presence of local traditions and identities;

- Lack of services;

- Presence of typical productive activities;

- Distance from the major cities;

- Lack of adequate infrastructure;

- Environmental quality;

- Insertion in a natural context;

- Limited and compact extension of the built fabric;

- 'Human scale' dimension of the built fabric;

- Quality of the built heritage;

- Site-specific typological-constructive characters.

\subsection{The Sub-Criteria}

The invariants were translated into one or more evaluation sub-criteria, following the correspondence shown in Table A1.

Once the sub-criteria were defined, all elements of the decision problem were hierarchically organised (Table A2).

As can be seen from Table A2, both environmental and historic-architectural subcriteria were broken down into the three layers, territory, urban core, building, in order to deepen the relationships between the three systems and to facilitate the examination of the strategies on several scales of intervention.

At the territorial level, the environmental issues include the components of the local flora and fauna, the water, the air, and the soil. At the urban core scale, the green spaces' composition, texture, and quality are analysed. As for the building, its bioclimatic characteristics are investigated.

With regard to the historic-architectural sub-criteria: the territory scale includes the relationship between landscape and village; for the urban core, the spatial and visual link between the historic centre and the administrative context is considered (the public green and equipped areas are evaluated along with circulation spaces, i.e., alleys, streets, stairs, covered passages, etc., and together with aggregation spaces, such as squares, open spaces, etc.); finally, the building is analysed both in its formal relationship with the whole small town and in its typological-constructive characteristics.

\subsection{New Datasets of Evaluation Indicators}

Once all elements were set up according to the hierarchical structure of the Analytic Hierarchy Process, appropriate evaluation indicators were associated with each sub-criteria.

This followed the study of datasets addressing the issues of 'urban sustainability', 'sustainable urban mobility', 'valorisation of the historical-cultural heritage', 'territorial cohesion', 'rural development', and 'landscape'. 
Thus 470 indicators were selected from 15 international studies [43-56]. Table A3 lists the 15 works, indicating the authors, years of publication, and panel titles.

From the 470 selected evaluation indexes, a further selection of indicators specifically linked to social, economic, environmental, and historic-architectural issues of small municipalities was made.

This second moment of selection was conducted in the light of the five principles $[57,58]$ :

- Focus, in order to identify those indices that exclusively measure what you need to measure;

- Relevance, in relation to the ongoing research;

- Accessibility, with regard to the facility to access the requested data;

- Clarity, as it is necessary to adopt clear indices, the measurement of which does not allow ambiguities of interpretation;

- Frequency, so as to favour those indicators that recur most frequently within the examined panels.

According to these requirements, four datasets of evaluation indicators were proposed: for the social criteria ( 24 indexes); for the economic one ( 42 indexes); for the environmental one (34 indexes); for the historic-architectural criteria (38 indexes).

It should be noted that all four datasets also include new indicators, defined to consider specific impacts that the investment project may have on the territory.

The proposed four panels are useful tools for all operators involved in the technicaleconomic evaluation of interventions for the recovery and valorisation of small towns in inland areas [59].

Tables A4-A7 show the datasets in detail. For each sub-criteria, several indicators are provided, among which the decision-maker can choose the indexes considered most appropriate to solve the specific evaluation problem.

\subsection{The Assignment of Weights}

Once the four panels of evaluation indicators were set up, the problem was to assign weights to the decision elements. According to the common practice, there is a general trend to assign the same weight to the criteria. At this level, in fact, the judgement is strongly conditioned by political decisions, rather than by technical evaluation rules. Therefore, by giving the same weight to the social, economic, environmental, and historic-architectural criteria, the idea is to defer to the political goals a decision that does not seem to find a different value assignment now.

This is different for the sub-criteria. Here, weights can be coherently attributed on the basis of the results of questionnaires administered to experts, who compare the sub-criteria with each other in order to assess their level of mutual importance.

\section{The Case Study}

The analysis model proposed in the previous section was applied to the Well-being Village project for the Riccia Municipality, a small town of 5068 inhabitants in the Province of Campobasso (Italy).

Riccia is a typical Italian small town affected by depopulation, recording a percentage change in the resident population of $-11.5 \%$ between 2001 and 2019 (ISTAT data, 2019) and a population loss of about $40 \%$ from the last century to date (years 1936-2020). Although the municipality is not far from the city of Campobasso (about $35 \mathrm{~min}$ by car), it does not have adequate infrastructure systems and lacks a railway station. On the other hand, the historic centre is characterised by narrow alleyways, stone stairways, load-bearing masonry buildings, and wooden and clay tile roofs. The architectural heritage includes many monuments (a castle, churches, and museums) and valuable buildings. These, in some cases, are marked by ancient family coats of arms or historical shop signs. Local traditions are still tangible in craft activities, food and wine festivals, and religious celebrations. However, as in many Italian municipalities, urban sprawl, although very limited, records the presence of new reinforced concrete buildings and prefabricated warehouses. 
This is the context in which the Riccia's Well-being Village project was set, whose tourist and residential purposes pay particular attention to protecting the health care of senior citizens. Financed by $€ 1,142,644$ from national Funds for Development and Cohesion $(29 \%)$ and European Funds for Regional Development $(71 \%)$, the investment includes the actions listed in Table 2 (documents of Riccia Municipality, Italy). Figure 1 shows the location of the interventions aimed at recovering and valorising the Riccia village.

Table 2. Historic-architectural criteria: dataset of indicators. The interventions and actions foreseen in the Well-being Village project (documents of Riccia Municipality, Italy).

\begin{tabular}{|c|c|}
\hline Main Intervention & Single Actions \\
\hline $\begin{array}{l}\text { Recovery of buildings (for a } \\
\text { total of } 1043 \mathrm{~m}^{2} \text { of net surface } \\
\text { area) to be converted into social } \\
\text { assistance and } \\
\text { tourist-residential facilities for } \\
\text { the elderly }\end{array}$ & $\begin{array}{l}\text { - Replacement of inter-floor and roof slabs (in cases where } \\
\text { it is no longer possible to recover the original ones) } \\
\text { - } \quad \text { Floor renovation/restoration } \\
\text { - Lifts installation } \\
\text { - Laying of underfloor heating systems and photovoltaic } \\
\text { panels, as well as water, electricity, gas, and telephone } \\
\text { networks } \\
\text { - New furniture }\end{array}$ \\
\hline $\begin{array}{l}\text { Renovation of the two main } \\
\text { squares in the historic town } \\
\text { centre (Piazza Sedati and Piazza } \\
\text { Municipio) next to the } \\
\text { recovered buildings }\end{array}$ & $\begin{array}{l}\text { - } \quad \text { Spatial-functional re-design of squares } \\
\text { - } \quad \text { Creation of green areas } \\
\text { - } \quad \text { New urban furniture } \\
\end{array}$ \\
\hline $\begin{array}{l}\text { Rehabilitation of footpaths and } \\
\text { streets in the historic town } \\
\text { centre }\end{array}$ & $\begin{array}{l}\text { - } \quad \text { Restoration of the original pavement } \\
\text { - } \quad \text { Safety of the road surface for cars } \\
\text { Renovation of the public lighting system using } \\
\text { energy-saving techniques }\end{array}$ \\
\hline $\begin{array}{l}\text { Free Wi-Fi to cover the entire } \\
\text { historic town centre }\end{array}$ & - \\
\hline $\begin{array}{l}\text { Creation of community } \\
\text { vegetable gardens }\end{array}$ & $\begin{array}{l}\text { Recovery of unused green areas to be converted into } \\
\text { public gardens for the use of residents }\end{array}$ \\
\hline $\begin{array}{l}\text { Creation of the Wellbeing Path } \\
\text { (via Trono and via Portella) }\end{array}$ & $\begin{array}{l}\text { - Safety of paths with fences and restoration of } \\
\text { rammed-earth flooring } \\
\text { - } \quad \text { Creation of equipped areas for outdoor gymnastic }\end{array}$ \\
\hline $\begin{array}{l}\text { Creation of common areas for } \\
\text { guests }\end{array}$ & $\begin{array}{ll}\text { - } & \text { Reception } \\
\text { - } & \text { Offices } \\
\text { - } & \text { Aggregation spaces } \\
\text { - } & \text { Restaurant/Canteen } \\
\text { - } & \text { Wellness centre }\end{array}$ \\
\hline $\begin{array}{l}\text { Recovery and valorisation of the } \\
\text { Santa Maria delle Grazie Church }\end{array}$ & $\begin{array}{l}\text { - } \quad \text { Securing the building structure } \\
\text { - } \quad \text { Exhibition and conference space } \\
\text { - } \quad \text { Small movie theatre }\end{array}$ \\
\hline Zero Waste Project & $\begin{array}{l}\text { - Construction of an ecological island with a composting } \\
\text { plant }\end{array}$ \\
\hline
\end{tabular}




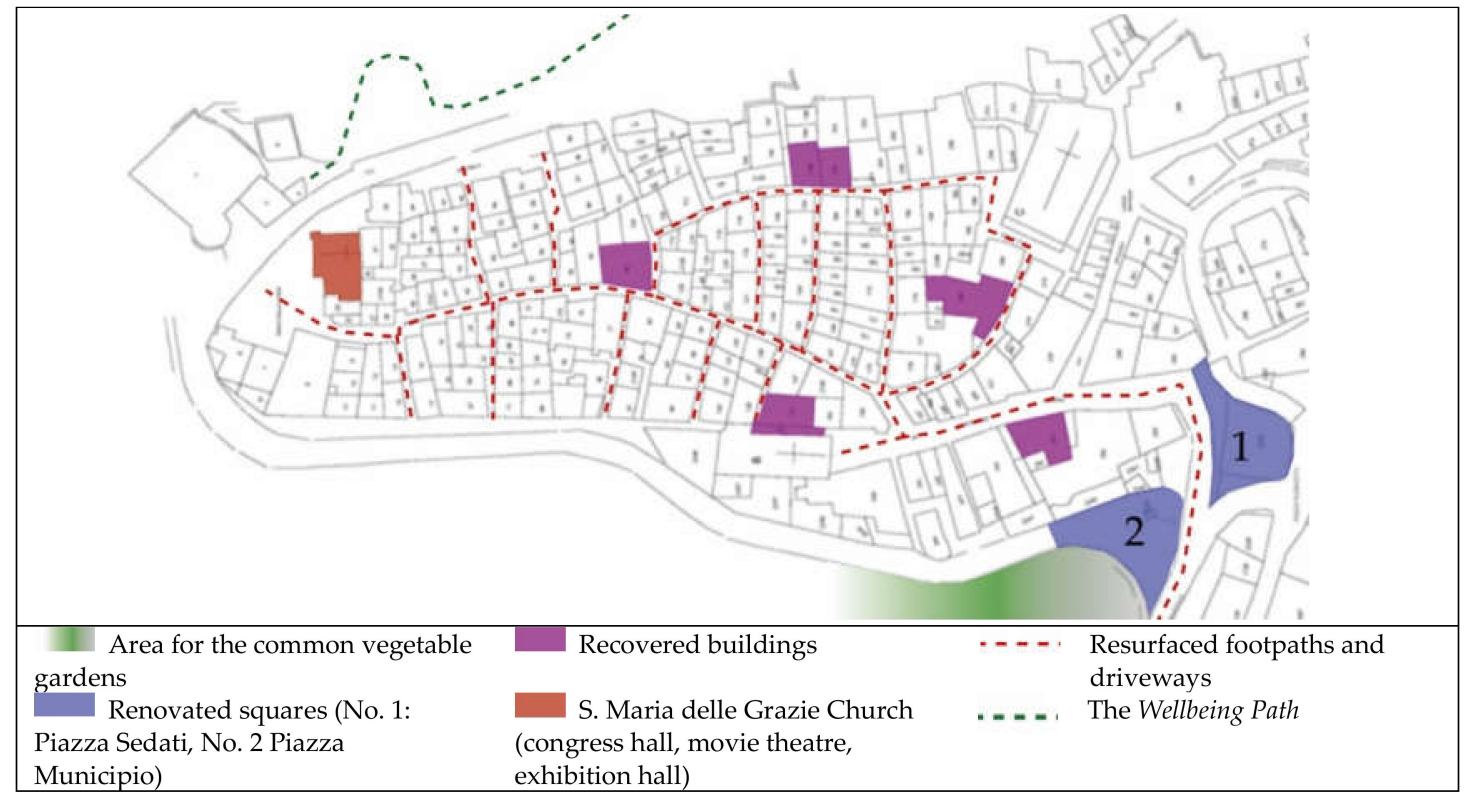

Figure 1. Interventions foreseen in the Well-being Village project (Source: Municipality of Riccia. Re-elaboration by the authors).

The model implementation requires the selection of indicators to evaluate the effectiveness of the actions planned in the Well-being Village project.

Given the social, economic, environmental, and historic-architectural criteria, the related sub-criteria were first investigated, and appropriately weighted through the use of questionnaires administered to experts. From the answers provided, pairwise comparison matrixes were built which, once normalised, returned the weights of each sub-criteria (Tables A8-A10). It was obtained that:

- With reference to the social criteria, in Riccia, traditions and secondary urbanisation works (schools, health centers, theatres, libraries, sports facilities, etc.) are more important (0.40) than assistance services for foreigners (0.20);

- According to the economic criteria, infrastructures (roads, public lighting, water, gas, electricity, sewage, broadband, etc.) and the productive vocations of the place (tourism, agriculture, livestock farming, crafts, etc.) are equally important;

- Under the environmental criteria, there is a higher incidence of both the bioclimatic quality of buildings (0.39) and the quality of water, air, and soil (0.32). The characteristics of flora and fauna as well as the state of preservation of green areas are of the same relevance (0.145).

The only exception was for the six historic-architectural sub-criteria, which were assigned the same weight (0.16) in view of their equal importance in the recovery and valorisation of the Riccia village.

At this point, depending on the available data and the specificities of the case study, the assessment index of the interventions was selected from Tables A4-A7 for each sub-criteria.

Tables A11-A14 show the correspondence between sub-criteria and the selected indicators.

Each indicator measures the project's ability to achieve the goal represented by the corresponding sub-criteria. This is carried out according to a scale of scores from 1 to 5 , where: 1 = very bad; 2 = insufficient; $3=$ sufficient; 4 = good; $5=$ excellent.

These judgments were made taking into account not only the effects of the strategy in the specific sectors at which the project is directed, but also other complementary actions aimed at improving the area's reception capacity, redeveloping public spaces and making them more accessible to tourists by providing street furniture, parking and rest areas, and visitor and thematic routes (documents of Riccia Municipality, Italy). 
Additional information useful to assign values to the indicators are based on: application of the formulas already shown in Tables A4-A7; questionnaires administered to the population; and references from legislation.

The values assigned to the indicators are in Tables A15-A18. The score $S$ of each indicator was multiplied with the weight $W$ of the related sub-criteria in order to obtain the weighted score $S_{w}$.

$S_{w}$ was compared with the maximum weighted score $S_{\max }$ relating to the reference indicator with the highest value, i.e., 5 . The comparison between $S_{w}$ and $S_{\max }$ allowed the verification of the acceptability of the project in relation to the sub-criteria under examination. In particular:

- If $S_{w} \geq 0.6 S_{\max }$, the project is effective in achieving the goals of the sub-criteria (accepted);

- If $S_{w}<0.6 S_{\max }$, the project does not achieve the goals (not accepted).

Thus, $60 \%$ of $S_{\max }$ is assumed as the acceptability threshold on a $0-100$ scale.

It should be noted that in some cases a 'composite' indicator was introduced. This means that the sub-criteria were evaluated by using a combination of two or more indicators, able to capture different components of the problem that the sub-criteria represent. In this case, $S_{w}$ is the product of the average of the scores assigned to the indicators and the weight given to the sub-criteria.

For example, with regard to the economic criteria, a composite indicator was considered for the sub-criteria Productive vocations, evaluated through: (1) Agricultural land use; (2) Skills recovery. Scores were given to these two indicators:

$$
\begin{gathered}
S_{\text {Agricultural land use }}=4 ; \\
S_{\text {Skills recovery }}=1 .
\end{gathered}
$$

Therefore, the weighted score $S_{w}=1.25$ for Productive vocations is the product of the weight 0.50 of the sub-criteria and the arithmetic average 2.5 of scores 4 and 1.

This approach makes it possible to highlight the project's ability to affect the individual components Agricultural land use and Skills recovery, which are essential for an effective interpretation of the Productive vocations sub-criteria. Obviously, for Productive vocations the value $S_{\max }=2.5$ is the product between the average value $S=5$ of the two indicators Agricultural land use and Skills recovery with maximum score and the weight $W=0.50$ of the sub-criteria. From the comparison between $S_{w}=1.25$ and Smax $=2.5$, it follows that $S_{w}=50 \% \cdot S_{\max }$. Thus, the $60 \%$ threshold is not satisfied; with regard to the subcriteria Productive vocations, the Well-being Village project is not acceptable and must be integrated and/or modified.

A composite indicator is also associated with the sub-criteria Primary urbanisation works, described through: Quality of the street and sidewalks cover; Percentage of houses with communications (including electricity, water, sewage, gas, heating, internet, phone lines); The number of public Wi-Fi places.

\section{Results Analysis}

The achieved results are as follows.

- Social criteria. The Riccia's Well-being Village project was accepted with regard to all the three assessment social sub-criteria. The project succeeded in valorising Local traditions and identities, effectively acting on Secondary urbanisation works and Social assistance service. Table A15 gives percentage values of $S_{w}$ compared to $S_{\max }$ above the $60 \%$ threshold for all the evaluation indexes. Specifically: $S_{w}=80 \% \cdot S_{\max }$ for Local traditions and identities; $S_{w}=80 \% \cdot S_{\max }$ for Secondary urbanization works; $S_{w}=100 \% \cdot S_{\max }$ for Social assistance service.

- Economic criteria. The project was accepted with respect to the sub-criteria Primary urbanization works, while for the Productive vocations component it did not reach the required sufficiency. Table A16 shows the percentage values of $S_{w}$ compared 
to $S_{\max }$ for both the sub-criteria: $S_{w}=100 \% \cdot S_{\max }$ for Primary urbanization works; $S_{w}=50 \% \cdot S_{\max }$ for Productive vocations. Thus, the model identified Productive vocations as a critical issue in the Well-being Village strategy. This means that the recovery and valorisation actions did not effectively look at the territory's traditional productive activities.

- Environmental criteria. Here all the assessment sub-criteria were accepted. The Well-being Village project paid particular attention to the Flora and fauna, Environmental quality, Green areas, and Bioclimatic quality components, recording the highest percentage values: $S_{w}=100 \% \cdot S_{\max }$ (Table A17).

- Historic-architectural criteria. The project was accepted with reference to the subcriteria Integration with the natural environment, Visual image, Dialogue between the historic urban fabric and its context, Empty/Full relationship and equipped green space system and Formal relationship between building and urban core. In fact, as shown in Table A18, the percentage values of $S_{w}$ were respectively: $S_{w}=100 \% \cdot S_{\max }$; $S_{w}=80.72 \% \cdot S_{\max } ; S_{w}=100 \% \cdot S_{\max } ; S_{w}=90.36 \% \cdot S_{\max } ; S_{w}=100 \% \cdot S_{\max }$. On the contrary, the Typological-distributive and formal characteristics of the building recorded the percentage $S_{w}=50.60 \% \cdot S_{\max }$. It follows that the $60 \%$ threshold was not satisfied for this sub-criteria. This underlines the inadequacy of the project actions with regard to the fruition of the recovered architectural heritage.

The model therefore identified two main criticalities in the Well-being Village strategy of the Riccia Municipality: one of economic order; the other one with respect to the historicarchitectural heritage.

On the economic issue, with particular reference to production vocations, it emerged that the inclusion of local craftsmen during the planning and execution phases of the works was limited, with certainly negative effects. The involvement of local craft workers is crucial to rebuild an 'original atmosphere', including old manual traditions passed down from generation to generation. The workforce could be employed not only in the production of furniture and objects, but also in the manufacture of floors and finishing elements. As shown by other valorisation strategies (the Albergo Diffuso of Santo Stefano di Sessanio in Abruzzo, the Ecovillage of Torri Superiore in Liguria, the Artists' Village of Calcata in Lazio, etc.), the use of ancient manufacturing knowledge is decisive in 'enlivening' a small municipality and rebuilding its identity and historical culture. Aiming at the productive vocations of a place means creating employment opportunities, but also investing in potentially profitable sectors, especially if reinterpreted in an original and modern key.

With regard to the reuse of the buildings, the developed model highlighted the project's lack of attention in defining the correct uses for the historic-architectural building heritage. Thus, the building interventions, although they delayed the degradation of the existing heritage, did not produce advantages in the works management phase.

In this sense, the weakness of Riccia's Well-being Village project can be traced back to the lack of a larger-scale approach able to relate the municipality to the neighbouring context. This means adopting an integrated strategy that strengthens the relations with surrounding cities in order to redefine the identity of the municipality in accordance with a territorial network of interdependence. Recent European projects (see Section 1) underline the need to re-include small towns in their reference territories through effective reciprocity and interconnection policies. In this respect, in the 2014-2020 territorial cohesion policy programme, the Smart Specialisation Strategy (S3), is a valuable tool for identifying investment priorities in the research and innovation sectors. Through a multi-level and multi-stakeholder analysis of a territory's production potential, the Smart Specialisation Strategy sets out medium- and long-term sustainable development paths.

In view of these considerations and of what has emerged from the tool's application to the Riccia case study, it is clear that intervening on the single small municipality is not enough, but it is essential to rethink the role of these places in relation to the territorial dynamics in which they are inserted. 
Therefore, in the light of the findings, it comes out that there is the capacity of the technical-economic assessment tool to investigate the criticalities of the Riccia's Well-being Village strategy, so as to guide the public decision-maker towards a more correct allocation of the available resources.

\section{Conclusions}

The valorisation of small towns has many advantages: reduction of urban decongestion, re-proposal of identity and social values, rehabilitation of the existing built heritage, less land consumption, reintroduction of typical productive activities, and promotion of local traditions.

Nevertheless, the multiple factors that characterise small municipalities make the effectiveness of the actions complex, requiring them to face significant social, economic, environmental, and cultural challenges. The risk is to invest resources in mostly punctual projects, which are not in line with the soul of the places and the real needs of the territory. Therefore, there is no doubt that the effectiveness of interventions lies in the ability to address, understand, and resolve issues of different natures within organic recovery projects. It is essential to extend the action field to the social (local traditions, 'genius loci', secondary urbanisation works, assistance services), economic (productive activities, primary urbanisation works), and environmental components (flora, fauna, air, water, soil, building bioclimatics) of the small towns, as well as to the historic-architectural aspects (visual-infrastructural-landscape connection between the village and the administrative context, formal correlation between the building and the urban cores, and typologicalconstructive characteristics of the architectural artefact). This is in view of the need to strengthen the relationship between small municipalities and the facilities of the territory to which they belong in order to guarantee an "information transfer" that can enhance the characteristics of each small town within a large-scale territorial network.

In view of the above, the paper outlined an innovative multi-criteria analysis tool in order to detect the criticalities and qualities of valorisation strategies. The proposed datasets of evaluation criteria, sub-criteria, and indicators may be used by stakeholders to assess investments, optimise project contents, and effectively guide future actions.

As it is set up, the model can be used not only to express a judgement on the 'post operam' recovery and valorisation interventions, but also on the 'ante operam' ones, foreseeing their repercussions in the social, economic, environmental, and historic-architectural fields both on small municipalities and on neighbouring territories.

Research prospects concern: the implementation of the model in hierarchical analysis schemes for the comparison between project alternatives; and the application to other case studies to test its full effectiveness and propose specific integrations to the datasets.

Author Contributions: Conceptualization, A.N. and P.F.; data curation, A.N. and E.D.; formal analysis, A.N., P.F. and E.D.; investigation, A.N., P.F. and E.D.; methodology, A.N., P.F. and E.D.; project administration, A.N. and P.F.; resources, E.D.; software A.N., P.F. and E.D.; supervision, A.N. and P.F.; validation, A.N., P.F. and E.D.; visualization, A.N., P.F. and E.D.; writing-original draft, A.N. and E.D.; writing-review and editing, A.N., P.F. and E.D. All authors have read and agreed to the published version of the manuscript.

Funding: This research received no external funding.

Institutional Review Board Statement: Not applicable.

Informed Consent Statement: Not applicable.

Conflicts of Interest: The authors declare no conflict of interest. 


\section{Appendix A}

Table A1. Correspondence between invariants and sub-criteria.

\begin{tabular}{|c|c|c|}
\hline Criteria & Invariant & Sub-Criteria \\
\hline \multirow{3}{*}{ Social } & Presence of local traditions and identities & Local traditions and identities \\
\hline & \multirow{2}{*}{ Lack of services } & Secondary urbanization works \\
\hline & & Social assistance services \\
\hline \multirow{3}{*}{ Economic } & Presence of typical productive activities & Productive vocations \\
\hline & Distance from the major cities & \multirow{2}{*}{ Primary urbanization works } \\
\hline & Lack of adequate infrastructure & \\
\hline \multirow{4}{*}{ Environmental } & \multirow{4}{*}{ Environmental quality } & Flora and fauna \\
\hline & & Environmental quality (water, air, soil) \\
\hline & & Green areas \\
\hline & & Bioclimatic quality \\
\hline \multirow{6}{*}{ Historic-architectural } & \multirow{2}{*}{ Insertion in a natural context } & Integration with the natural environment \\
\hline & & Visual image (evocative force) \\
\hline & $\begin{array}{l}\text { Limited and compact extension of the built } \\
\text { fabric }\end{array}$ & $\begin{array}{c}\text { Dialogue between the historic urban fabric and } \\
\text { its context }\end{array}$ \\
\hline & 'Human scale' dimension of the built fabric & $\begin{array}{l}\text { Full/empty relationship and equipped green } \\
\text { space system }\end{array}$ \\
\hline & Quality of the built heritage & $\begin{array}{l}\text { Formal relationship between building and } \\
\text { urban core }\end{array}$ \\
\hline & Site-specific typological-constructive characters & $\begin{array}{l}\text { Typological-distributive and formal } \\
\text { characteristics of the building }\end{array}$ \\
\hline
\end{tabular}

Table A2. Hierarchical diagram with goal, criteria, and sub-criteria.

\begin{tabular}{|c|c|c|c|c|}
\hline \multirow{2}{*}{$\begin{array}{c}\text { Goal } \\
\text { Criteria }\end{array}$} & \multicolumn{4}{|c|}{ Small Towns Valorization } \\
\hline & Social & Economic & Environmental & Historical-architectural \\
\hline \multirow{9}{*}{ Sub-criteria } & \multirow{9}{*}{$\begin{array}{l}\text { Local traditions and } \\
\text { identities } \\
\text { Secondary urbanization } \\
\text { works (kindergartens, } \\
\text { schools, health facilities) } \\
\\
\text { Social assistance services } \\
\text { (services for the elderly, for } \\
\text { disabled people, for } \\
\text { immigrants) }\end{array}$} & \multirow{9}{*}{$\begin{array}{l}\text { Productive vocations } \\
\text { (agriculture, crafts, industry, } \\
\text { commerce, tourism) } \\
\text { Primary urbanization works } \\
\text { (roads, parking lots, } \\
\text { electricity network, teleph. } \\
\text { network, gas network, } \\
\text { public lighting, water } \\
\text { network) }\end{array}$} & Territory & Territory \\
\hline & & & Flora and fauna & \\
\hline & & & $\begin{array}{l}\text { Environmental quality } \\
\text { (water, air, soil) }\end{array}$ & $\begin{array}{l}\text { Integration with the natural } \\
\text { environment }\end{array}$ \\
\hline & & & Urban core & Urban core \\
\hline & & & \multirow[t]{2}{*}{ Green areas } & $\begin{array}{l}\text { Visual image } \\
\text { Dialogue between the historic } \\
\text { urban fabric and its context }\end{array}$ \\
\hline & & & & $\begin{array}{l}\text { Full/empty relationship and } \\
\text { equipped green space system }\end{array}$ \\
\hline & & & Building & Building \\
\hline & & & \multirow[b]{2}{*}{ Bioclimatic quality } & $\begin{array}{l}\text { Formal relationship between } \\
\text { building and urban core }\end{array}$ \\
\hline & & & & $\begin{array}{c}\text { Typological-distributive and } \\
\text { formal characteristics of the } \\
\text { building }\end{array}$ \\
\hline
\end{tabular}


Table A3. International reference studies.

\begin{tabular}{|c|c|c|c|}
\hline Author(s) & Year & Title & N. Indicators \\
\hline Mega V., Pedersen J. & 1998 & $\begin{array}{l}\text { Urban Sustainability } \\
\text { Indicators }\end{array}$ & 16 \\
\hline European Commission & 2008 & $\begin{array}{c}\text { European Green Capital } \\
\text { Award }\end{array}$ & 12 \\
\hline Mameli F., Marletto G. & 2009 & $\begin{array}{l}\text { A selection of indicators for } \\
\text { monitoring sustainable urban } \\
\text { mobility policies }\end{array}$ & 14 \\
\hline Vallega A. & 2009 & Indicatori per il paesaggio & 37 \\
\hline $\begin{array}{c}\text { European Environment } \\
\text { Agency }\end{array}$ & 2010 & $\begin{array}{c}\text { EEA Urban Metabolism } \\
\text { Framework }\end{array}$ & 15 \\
\hline $\begin{array}{c}\text { United Nations Economic } \\
\text { Commission for Europe } \\
\text { (UNECE) }\end{array}$ & 2011 & $\begin{array}{c}\text { Transport for sustainable } \\
\text { development in the ECE } \\
\text { region }\end{array}$ & 17 \\
\hline Volpiano M. & 2011 & $\begin{array}{c}\text { Indicators for the Assessment } \\
\text { of Historic Landscape } \\
\text { Features }\end{array}$ & 12 \\
\hline Swiss Confederation & 2012 & $\begin{array}{c}\text { Ufficio Federale dell'Ambiente } \\
\text { UFAM - Paesaggio: } \\
\text { Indicatori }\end{array}$ & 11 \\
\hline $\begin{array}{l}\text { EU Commission, } \\
\text { Directorate-General for } \\
\text { Agriculture and Rural } \\
\text { Development }\end{array}$ & 2013 & $\begin{array}{l}\text { Rural Development in the } \\
\text { European Union - Statistical } \\
\text { and Economic Information, } \\
\text { Report } 2013\end{array}$ & 59 \\
\hline $\begin{array}{c}\text { European Spatial Planning } \\
\text { Observation Network }\end{array}$ & 2013 & $\begin{array}{l}\text { KITCASP - Key Indicatorsfor } \\
\text { Territorial Cohesion and } \\
\text { Spatial Planning }\end{array}$ & 20 \\
\hline Phillips R. G., Stein J. M. & 2013 & $\begin{array}{c}\text { An Indicator Framework for } \\
\text { Linking Historic Preservation } \\
\text { and Community Economic } \\
\text { Development }\end{array}$ & 29 \\
\hline $\begin{array}{c}\text { Valtenbergs V., González } \\
\text { A., Piziks R. }\end{array}$ & 2013 & $\begin{array}{l}\text { Selecting indicators for } \\
\text { sustainabledevelopment of } \\
\text { small towns: the case of } \\
\text { Valmiera municipality }\end{array}$ & 73 \\
\hline $\begin{array}{l}\text { European Environment } \\
\text { Agency }\end{array}$ & 2014 & $\begin{array}{c}\text { Digest of EEA Indicators } \\
2014 \text { - Core Set of Indicators } \\
\text { (CSI) }\end{array}$ & 42 \\
\hline $\begin{array}{l}\text { UN-Habitat - United } \\
\text { Nations Human } \\
\text { Settlements Programme }\end{array}$ & 2016 & $\begin{array}{l}\text { MEASUREMENT OF CITY } \\
\text { PROSPERITY - Methodology } \\
\text { and Metadata }\end{array}$ & 39 \\
\hline \multirow[t]{2}{*}{$\begin{array}{l}\text { Bosch P., Jongeneel S., } \\
\text { Rovers V., Neumann H-M., } \\
\text { Airaksinen M., Huovila A. }\end{array}$} & 2017 & $\begin{array}{l}\text { CITYkeys list of city } \\
\text { indicators }\end{array}$ & 74 \\
\hline & & TOT. & 470 \\
\hline
\end{tabular}


Table A4. Social criteria: dataset of indicators.

\begin{tabular}{|c|c|c|c|}
\hline \multicolumn{4}{|c|}{ SOCIAL CRITERIA } \\
\hline Sub-Criteria & & Indicator & Description \\
\hline \multirow[b]{6}{*}{$\begin{array}{l}\text { Local traditions } \\
\text { and identities }\end{array}$} & \multirow{5}{*}{ 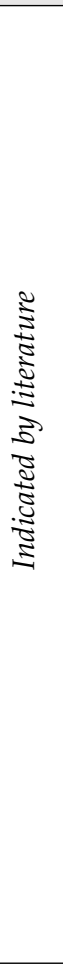 } & $\begin{array}{l}\text { Sense of place/identification } \\
\text { with place/attachement to place }\end{array}$ & $\begin{array}{l}\text { The way people perceive the resources and historical environment } \\
\text { of their community. There is an identity linked to the place that } \\
\text { evokes a special sense of place. This indicator requires a direct } \\
\text { survey among the inhabitants of the historical sites. }\end{array}$ \\
\hline & & The number of cultural events & $\begin{array}{l}\text { n. of cultural events. } \\
\text { Did the implemented strategy safeguard and/or support cultural } \\
\text { events? YES/NO. }\end{array}$ \\
\hline & & $\begin{array}{l}\text { The number of visitors in } \\
\text { cultural events }\end{array}$ & $\mathrm{n}$. visitors in cultural events. \\
\hline & & Taste's places & $\begin{array}{l}\text { It is evaluated by the level at which the "taste's places" enter into } \\
\text { landscape valorization policies } \\
I=\frac{G_{c}}{G_{t}} \times 100 \\
G_{c} \text { expresses the number of "taste's places" subject to interventions } \\
\text { and measures included in the territorial plans, aimed at enhancing } \\
\text { their value in relation to the landscape. } \\
G_{t} \text { expresses the total number of "taste's places" existing in the } \\
\text { considered territory. }\end{array}$ \\
\hline & & Event places & $\begin{array}{l}\text { It is assessed by the degree to which "event places" are included in } \\
\text { the perception of the landscape and are enhanced through ad hoc } \\
\text { measures } \\
I=\frac{E_{c}}{E_{t}} \times 100 \\
E_{c} \text { expresses the number of "event places" subject to interventions } \\
\text { and measures included in the territorial plans, aimed at enhancing } \\
\text { their value in relation to the landscape. } E_{t} \text { expresses the total } \\
\text { number of "event places" existing in the considered territory. }\end{array}$ \\
\hline & $\begin{array}{l}\widetilde{d} \\
\infty \\
\vdots \\
\vdots \\
\Sigma\end{array}$ & $\begin{array}{l}\text { Number of traditions (fables, } \\
\text { historical events, music) / } \\
\text { religious traditions / } \\
\text { gastronomic traditions / } \\
\text { festivals, exhibitions and } \\
\text { markets }\end{array}$ & $\begin{array}{l}\text { n. of oral, religious, gastronomic traditions, festivals, fairs, and } \\
\text { markets. } \\
\text { Has the implemented strategy safeguarded and/or supported local } \\
\text { traditions? YES/NO. }\end{array}$ \\
\hline & & Land Use Mix & $\begin{array}{l}\text { Land use diversity per square kilometre, within a city or urban area } \\
\text { (residential, commercial, and services, industrial, public facilities, } \\
\text { and public spaces). }\end{array}$ \\
\hline & & Land use change & $\begin{array}{l}\% \text { of total (building, roads, domestic, green space, agricultural, } \\
\text { woodland, water, etc.). }\end{array}$ \\
\hline & & $\begin{array}{l}\text { Access to services (hospitals } \\
\text { and schools) }\end{array}$ & Travel time (minutes) to hospitals/schools. \\
\hline & & $\begin{array}{l}\text { Access to basic health care } \\
\text { services }\end{array}$ & $\%$ of people. \\
\hline & & $\begin{array}{l}\text { Access to local/neighbourhood } \\
\text { services within a short distance }\end{array}$ & $\begin{array}{l}\text { Not specified in the bibliographical reference. It is proposed the } \\
\text { distance in } \mathrm{km} \text { to reach the nearest services. }\end{array}$ \\
\hline & & Unemployment structure & $\begin{array}{l}\text { Not specified in the bibliographical reference. It is proposed the } \% \\
\text { of unemployed residents. }\end{array}$ \\
\hline & & Social Justice Indicator & $\begin{array}{l}\text { Percentage of the population affected by poverty, unemployment, } \\
\text { lack of access to education, information, training, and leisure. }\end{array}$ \\
\hline & & Development of service sector & $\begin{array}{l}\text { This indicator measures the share of Gross Value Added (GVA) in } \\
\text { the services sector in a region. }\end{array}$ \\
\hline & & Access to public amenities & $\%$ of people \\
\hline & & Access to commercial amenities & $\%$ of people \\
\hline & & Access to educational resources & $\begin{array}{l}\text { Likert's scale. Wherever possible, the use of the percentage of the } \\
\text { population accessing educational resources is suggested. }\end{array}$ \\
\hline & & & Number of public libraries per 100,000 people (n. $/ 100,000$ people) \\
\hline & & Number of public libraries & $\begin{array}{l}\text { or No. public libraries/lotal libraries. } \\
\text { Did the strategy include new public bookshops/libraries? } \\
\text { YES/NO. }\end{array}$ \\
\hline
\end{tabular}


Table A4. Cont.

\begin{tabular}{|c|c|c|c|}
\hline \multicolumn{4}{|c|}{ SOCIAL CRITERIA } \\
\hline \multicolumn{2}{|l|}{ Sub-Criteria } & Indicator & Description \\
\hline & $\stackrel{2}{\Xi}$ & $\begin{array}{l}\text { The number of assistance } \\
\text { centers }\end{array}$ & n. of assistance centers. \\
\hline & 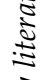 & Net migration & $\begin{array}{l}\text { It's the ratio of net migration during the year to the average } \\
\text { population in that year. It is also possible to use: } n . / 1000 \text {. }\end{array}$ \\
\hline & $\frac{\vec{\Xi}}{\vec{\Xi}}$ & $\begin{array}{l}\text { Average number of assistance } \\
\text { hours per year }\end{array}$ & Average number of assistance hours per year. \\
\hline & 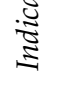 & $\begin{array}{l}\text { Percentage difference between } \\
\text { the offered services level and } \\
\text { the standard services level }\end{array}$ & $\begin{array}{l}\text { Percentage difference between the offered services level and the } \\
\text { standard services level. }\end{array}$ \\
\hline & & Quantitative level of benefits & $\begin{array}{l}\text { To be estimated on the most appropriate evaluation scale, } \\
\text { depending on the available information framework. }\end{array}$ \\
\hline & $\begin{array}{c}\varpi^{2} \\
\vdots \\
\vdots \\
\vdots \\
\vdots\end{array}$ & $\begin{array}{l}\text { Percentage of those who benefit } \\
\text { from social assistance services } \\
\text { on the resident population }\end{array}$ & $\begin{array}{l}\% \text { of population benefiting from social assistance services/total } \\
\text { resident population. }\end{array}$ \\
\hline
\end{tabular}

Table A5. Economic criteria: dataset of indicators.

\begin{tabular}{|c|c|c|c|}
\hline \multicolumn{4}{|c|}{ ECONOMIC CRITERIA } \\
\hline Sub-criteria & & Indicator & Description \\
\hline & \multirow{16}{*}{ 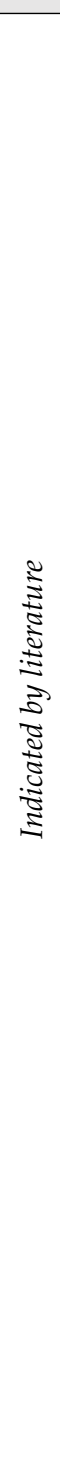 } & $\begin{array}{l}\text { Forest areas extensively } \\
\text { exploited }\end{array}$ & $\begin{array}{l}\text { Not specified in the bibliographical reference. It is proposed the } \\
\text { surface in } \mathrm{m} 2 \text { of extensively exploited forest areas. }\end{array}$ \\
\hline & & Agricultural areas & $\begin{array}{l}\text { Not specified in the bibliographical reference. It is proposed the } \\
\text { surface in } \mathrm{km} 2 \text { of agricultural areas. }\end{array}$ \\
\hline & & & $\begin{array}{l}\text { Shows the level (high or low) through which a city focuses its } \\
\text { economic activities on certain goods and services } \\
H=\sum_{i=1}^{N} S_{i}^{2}\end{array}$ \\
\hline & & Economic specialization & $\begin{array}{l}S_{i}{ }^{2} \text { is the employment share in the city's industry. This share is } \\
\text { expressed with a number and not a percentage. } \\
N \text { is the total number of industries. } \\
H \text { varies from } 1 / N \text { to } 1 \text {. A value of } H \text { greater than } 0,25 \text { indicates a } \\
\text { high concentration. }\end{array}$ \\
\hline & & Structure of the economy & $\%$ GVA by branch (primary/secondary/tertiary sector. \\
\hline & & Land use efficiency & $\begin{array}{l}\text { Not specified in the bibliographical reference. It is proposed to } \\
\text { make use of expert judgements, from which a quantitative } \\
\text { evaluation algorithm can be deduced. }\end{array}$ \\
\hline & & $\begin{array}{l}\text { Distribution of businesses and } \\
\text { employed by industries }\end{array}$ & $\begin{array}{l}\text { Not specified in the bibliographical reference. It is proposed the } \\
\text { number of employees in the industrial sector. }\end{array}$ \\
\hline & & The number of tourists & $\begin{array}{l}\text { Not specified in the bibliographical reference. It is proposed the } \\
\text { number of tourists per year. }\end{array}$ \\
\hline & & Foreign Direct Investments & Capital/Earnings. \\
\hline & & Accomodation load & $\begin{array}{l}\text { Not specified in the bibliographical reference. It is proposed the } \\
\text { accommodation capacity of the structures (hotels, hostels, b\&b, etc.) } \\
\text { as number of beds. }\end{array}$ \\
\hline & & $\begin{array}{l}\text { Dynamics of foundation and } \\
\text { dissolution of local businesses }\end{array}$ & $\begin{array}{l}\text { Not specified in the bibliographical reference. An economic } \\
\text { indicator is proposed, depending on the level of information } \\
\text { available. }\end{array}$ \\
\hline & & The number of guest nights & Number of guest nights. \\
\hline & & $\begin{array}{l}\text { Economic enhancement of } \\
\text { historical-cultural heritage } \\
\text { networking }\end{array}$ & $\begin{array}{l}\text { It is proposed to evaluate this parameter according to the } \\
\text { specificities of the case study. }\end{array}$ \\
\hline & & Agricultural land use & $\begin{array}{l}\% \text { of Utilised Agricultural Area (UAA) in arable land/permanent } \\
\text { pasture/permanent crops. }\end{array}$ \\
\hline & & $\begin{array}{l}\text { Economic development of } \\
\text { non-agricultural sector }\end{array}$ & GVA (million EUR) in secondary and tertiary sectors. \\
\hline & & $\begin{array}{l}\text { Tourism infrastructure in rural } \\
\text { areas }\end{array}$ & Total number of bed places in tourist accommodations (\%). \\
\hline
\end{tabular}


Table A5. Cont.

\begin{tabular}{|c|c|c|c|}
\hline \multicolumn{4}{|c|}{ ECONOMIC CRITERIA } \\
\hline \multirow[t]{8}{*}{ Sub-criteria } & & Indicator & Description \\
\hline & & Tourism intensity & n./100.000. \\
\hline & & Local food production & $\%$ of tonnes. \\
\hline & & Green jobs & $\%$ of jobs. \\
\hline & & Land use change & $\begin{array}{l}\% \text { of total (building, roads, domestic, green space, agricultural, } \\
\text { woodland, water, etc.). }\end{array}$ \\
\hline & & Skills recovery & Has the strategy promoted the recovery of local skills? YES/NO. \\
\hline & & Real estate value increase & $\%$ increase in real estate value driven by strategy. \\
\hline & & Prevailing cultivation & $\%$ of cultivations. \\
\hline \multirow{24}{*}{$\begin{array}{l}\text { Primary } \\
\text { urbanization } \\
\text { works }\end{array}$} & \multirow{22}{*}{ 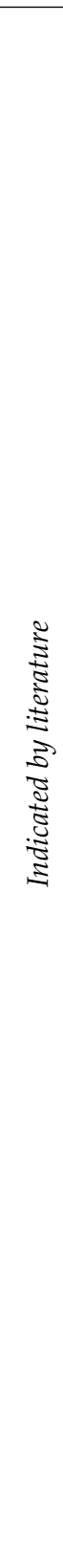 } & $\begin{array}{l}\text { Length of mass transport } \\
\text { network }\end{array}$ & $\mathrm{Km} / 1,000,000$ people \\
\hline & & Length of bike route network & $\%$ in $\mathrm{km}$ \\
\hline & & Public transport network length & $\begin{array}{l}\text { Not specified in the bibliographical reference. It is proposed the } \\
\text { route length in } \mathrm{km} \text { (tram, trolleybus, bus). }\end{array}$ \\
\hline & & Street intersection density & $\begin{array}{l}\text { Number of street intersections per one square kilometer of urban } \\
\text { area }\left(\mathrm{n} . / \mathrm{km}^{2}\right) .\end{array}$ \\
\hline & & Street density & $\begin{array}{l}\text { Number of kilometers of urban streets per square kilometer of land } \\
\left(\mathrm{km} / \mathrm{km}^{2}\right) .\end{array}$ \\
\hline & & Infrastructure density & $\mathrm{km}$ of roads per 1,000 inhabitants. \\
\hline & & Infrastructure quality & $\begin{array}{l}\text { Not specified in the bibliographical reference. It is proposed the \% } \\
\text { of road surface that is asphalted or in good condition (no holes, } \\
\text { cracks, depressions, spalling, bulges) over the total existing road } \\
\text { surface. }\end{array}$ \\
\hline & & $\begin{array}{l}\text { Percentage of houses with } \\
\text { communications (including } \\
\text { electricity, water, sewage, gas, } \\
\text { heating, internet, phone lines) }\end{array}$ & $\begin{array}{l}\% \text { of houses equipped with electrical system, water system, } \\
\text { purification system, gas, heating, internet, telephone line. }\end{array}$ \\
\hline & & $\begin{array}{l}\text { The number of public Wi-Fi } \\
\text { places }\end{array}$ & Number of public spaces equipped with Wi-Fi. \\
\hline & & $\begin{array}{l}\text { Public and private services } \\
\text { accessibile via telephone and } \\
\text { computer }\end{array}$ & $\begin{array}{l}\text { Not specified in the bibliographical reference. The indicator should } \\
\text { be chosen according to the data availability. }\end{array}$ \\
\hline & & $\begin{array}{l}\text { Transportation mode split } \\
\text { (percentage of each mode of } \\
\text { transportation, i.e. private, } \\
\text { public, bicycles, pedestrians) }\end{array}$ & $\%$ of each transport mode (public, private, cycle, walking). \\
\hline & & Internet access & $\begin{array}{l}\text { It is the ratio between the total number of Internet users in a city } \\
\text { and the total population of the same city }(\%) \text {. }\end{array}$ \\
\hline & & Home computer access & $\begin{array}{l}\text { Percentage of families owning household computers compared to } \\
\text { the total number of families in the city }(\%) \text {. }\end{array}$ \\
\hline & & Internet infrastructure & Families with DSL coverage (\%). \\
\hline & & Internet take-up in rural areas & $\begin{array}{l}\text { Families with a broadband connection contract ( } \% \text { of families with } \\
\text { at least one member aged between } 16 \text { and } 74 \text { years). }\end{array}$ \\
\hline & & Access to electricity & Percentage of families connected to the national network. \\
\hline & & Access to public transport & $\%$ of people \\
\hline & & Access to high speed internet & $\#(\mathrm{n}) / 100$. \\
\hline & & Access to public free WiFi & $\%$ of $\mathrm{m}^{2}$ \\
\hline & & Public transport use & $\#(n$.$) / cap / year$ \\
\hline & & $\begin{array}{l}\text { Land occupied by transport } \\
\text { infrastructures }\end{array}$ & $\begin{array}{l}\text { Not specified in the bibliographical reference. A percentage } \\
\text { evaluation is proposed. }\end{array}$ \\
\hline & & $\begin{array}{l}\text { Quality of the street and } \\
\text { sidewalks cover }\end{array}$ & $\begin{array}{l}\text { Not specified in the bibliographical reference. It is proposed the use } \\
\text { of expert judgements (scoring scale). }\end{array}$ \\
\hline & \multirow{2}{*}{ 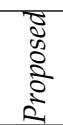 } & $\%$ of public transport & $\%$ \\
\hline & & $\begin{array}{l}\text { Sewerage meters in good } \\
\text { condition }\end{array}$ & $\begin{array}{l}\text { Did the strategy include the replacement of degraded sewer } \\
\text { sections? YES/NO. }\end{array}$ \\
\hline
\end{tabular}


Table A6. Environmental criteria: dataset of indicators.

\begin{tabular}{|c|c|c|}
\hline \multicolumn{3}{|c|}{ ENVIRONMENTAL CRITERIA } \\
\hline Sub-Criteria & Indicator & Description \\
\hline \multicolumn{3}{|c|}{ Territory } \\
\hline \multirow{20}{*}{ Flora and fauna } & Land cover & $\%$ area in agricultural/forest/natural classes. \\
\hline & Protected forest & $\begin{array}{l}\text { Not specified in the bibliographical reference. It is } \\
\text { proposed an evaluation based on the extension in } \mathrm{m}^{2}\end{array}$ \\
\hline & $\begin{array}{l}\text { The number of protected animal and plant } \\
\text { species }\end{array}$ & n. of protected animal and plant species. \\
\hline & $\begin{array}{l}\text { Percentage of preserved } \\
\text { area/reservoirs/waterways/parks in } \\
\text { relation to total land area }\end{array}$ & $\begin{array}{l}\% \text { areas, reserves, rivers, protected parks in relation to } \\
\text { the total territorial area. }\end{array}$ \\
\hline & Species and habitats of European interest & $\begin{array}{l}\text { Not specified in the bibliographical reference. It is } \\
\text { proposed the use of a numerical or percentage data. }\end{array}$ \\
\hline & $\begin{array}{l}\text { Number and status of protected European } \\
\text { habitats and species }\end{array}$ & $\begin{array}{l}\text { Number and Conservation Status (EU defined status } \\
\text { of Natura } 2000 \text { sites-SACs and SPAs and Annexed } \\
\text { species). }\end{array}$ \\
\hline & Designated areas & $\begin{array}{l}\mathrm{km}^{2}, \% \text {, number of species and habitats listed by the } \\
\text { Habitats Directive. }\end{array}$ \\
\hline & Land take & Hectares or $\mathrm{km}^{2}$ \\
\hline & Urban land take & $\begin{array}{l}\% \text { of land that is converted from natural and } \\
\text { semi-natural areas (including wooded and } \\
\text { agricultural areas) to artificial land used for urban and } \\
\text { economic purposes. }\end{array}$ \\
\hline & Proportion of protected areas & $\begin{array}{l}\text { Not specified in the bibliographical reference. It is } \\
\text { proposed the } \% \text { of protected natural areas on the total } \\
\text { number of existing natural areas. }\end{array}$ \\
\hline & Biodiversity: Tree species composition & $\begin{array}{l}\text { Area of forest classified by number of tree species } \\
\text { occurring and by forest type }(\%) \text {. } \\
\text { _ Share of FOWL protected under MCPFE classes (\%) }\end{array}$ \\
\hline & Biodiversity: Protected forest & $\begin{array}{l}\text { _Change of FOWL area protected under MCPFE } \\
\text { classes (ha) }\end{array}$ \\
\hline & Forest ecosystem health & $\begin{array}{l}\% \text { of sampled trees in defoliation classes } 2-4 \text { (all } \\
\text { trees/conifers/broadleaves). }\end{array}$ \\
\hline & Protected areas and elements & $\begin{array}{l}\text { Surface extension. Level of environmental protection. } \\
\text { Number of protected elements. Other specific } \\
\text { indicators. }\end{array}$ \\
\hline & & $\begin{array}{l}\% \text { of surface area subject to ecological protection } \\
\text { measures in relation to the total surface area } \\
I=\frac{S_{p}}{S_{t}} \times 100\end{array}$ \\
\hline & Ecologically protected areas & $\begin{array}{l}S_{p} \text { is the area in hectares (ha) subject to protection } \\
\text { measures. }\end{array}$ \\
\hline & & $\begin{array}{l}S_{t} \text { is the total area, expressed in hectares (ha), of the } \\
\text { considered territory. }\end{array}$ \\
\hline & & $\begin{array}{l}\% \text { of protected plant and/or animal species in relation } \\
\text { to all existing plant and/or animal species } \\
I=\frac{S_{p}}{S} \times 100\end{array}$ \\
\hline & Protected species & $\begin{array}{l}S_{p} \text { is the number of species, belonging to the wild } \\
\text { vegetation, subject to protective measures. }\end{array}$ \\
\hline & & $\begin{array}{l}S_{t} \text { is the number of species, belonging to spontaneous } \\
\text { vegetation, existing at the time the survey is } \\
\text { carried out. }\end{array}$ \\
\hline
\end{tabular}


Table A6. Cont.

\begin{tabular}{|c|c|c|c|}
\hline \multicolumn{4}{|c|}{ ENVIRONMENTAL CRITERIA } \\
\hline Sub-Criteria & & Indicator & Description \\
\hline \multicolumn{4}{|c|}{ Territory } \\
\hline \multirow{14}{*}{$\begin{array}{c}\text { Environ- } \\
\text { mental qual-ity } \\
\text { (water, air, soil) }\end{array}$} & \multirow{13}{*}{ 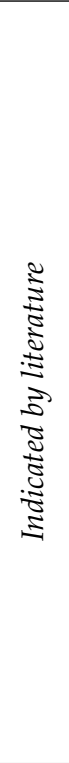 } & $\begin{array}{l}\text { Renewable energy production (wind, } \\
\text { hydro, biomass, etc.) }\end{array}$ & Megawatts and \% by renewable energy type. \\
\hline & & Greenhouse gas emissions & Tonnes $\mathrm{CO}_{2}$ eq. per individual. \\
\hline & & Water quality & Specific quality indicator. \\
\hline & & Water quality status & $\begin{array}{l}\text { Absolute values on the actual status or objective } \\
\text { met/failed (as per WFD for groundwater, rivers, lakes, } \\
\text { estauarine, coastal). }\end{array}$ \\
\hline & & Air quality & Specific quality indicator. \\
\hline & & Emissions of main air pollutants & Specific indicator. \\
\hline & & $\begin{array}{l}\text { Exposure of ecosystems to acidification, } \\
\text { eutrophication and ozone }\end{array}$ & Specific indicator. \\
\hline & & $\begin{array}{l}\text { Exceedance of air quality limit values in } \\
\text { urban areas }\end{array}$ & Specific indicator. \\
\hline & & $\begin{array}{l}\text { Atmospheric greenhouse gas } \\
\text { concentrations }\end{array}$ & Specific indicator. \\
\hline & & Green growth and eco-innovation & Specific indicator. \\
\hline & & Global Climate Indicator (GCI) & Emitted total $\mathrm{CO}_{2}, \mathrm{CH}_{4}, \mathrm{~N}_{2} \mathrm{O}$ and $\mathrm{CFC}$ and halons. \\
\hline & & $\mathrm{CO}_{2}$ emissions & Specific indicator. \\
\hline & & $\begin{array}{l}\text { Emission of greenhouse gases and local } \\
\text { pollutants }\end{array}$ & Specific indicator. \\
\hline & $\begin{array}{l}\tilde{\Xi} \\
\infty \\
\vdots \\
\vdots \\
2\end{array}$ & Presence of treatment systems & YES/NO. \\
\hline \multicolumn{4}{|c|}{ Urban core } \\
\hline Green areas & & $\begin{array}{l}\text { Green area per capita } \\
\text { Green space }\end{array}$ & $\begin{array}{l}\text { Green surface per capita. } \\
\text { Hectares } / 100,000 \text { or } \mathrm{m}^{2} \text { of green space per inhabitant. }\end{array}$ \\
\hline \multicolumn{4}{|c|}{ Building } \\
\hline \multirow{4}{*}{$\begin{array}{l}\text { Bioclimatic } \\
\text { quality }\end{array}$} & \multirow{4}{*}{ 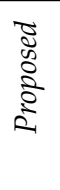 } & Shape and orientation & Type of shape. Building orientation. \\
\hline & & Ventilation quality & $\begin{array}{l}\text { Presence/absence of internal ventilation. Ventilation } \\
\text { level. }\end{array}$ \\
\hline & & Energy class & Level. \\
\hline & & Use of photovoltaic or solar panels & YES/NO. \\
\hline
\end{tabular}


Table A7. Historic-architectural criteria: dataset of indicators.

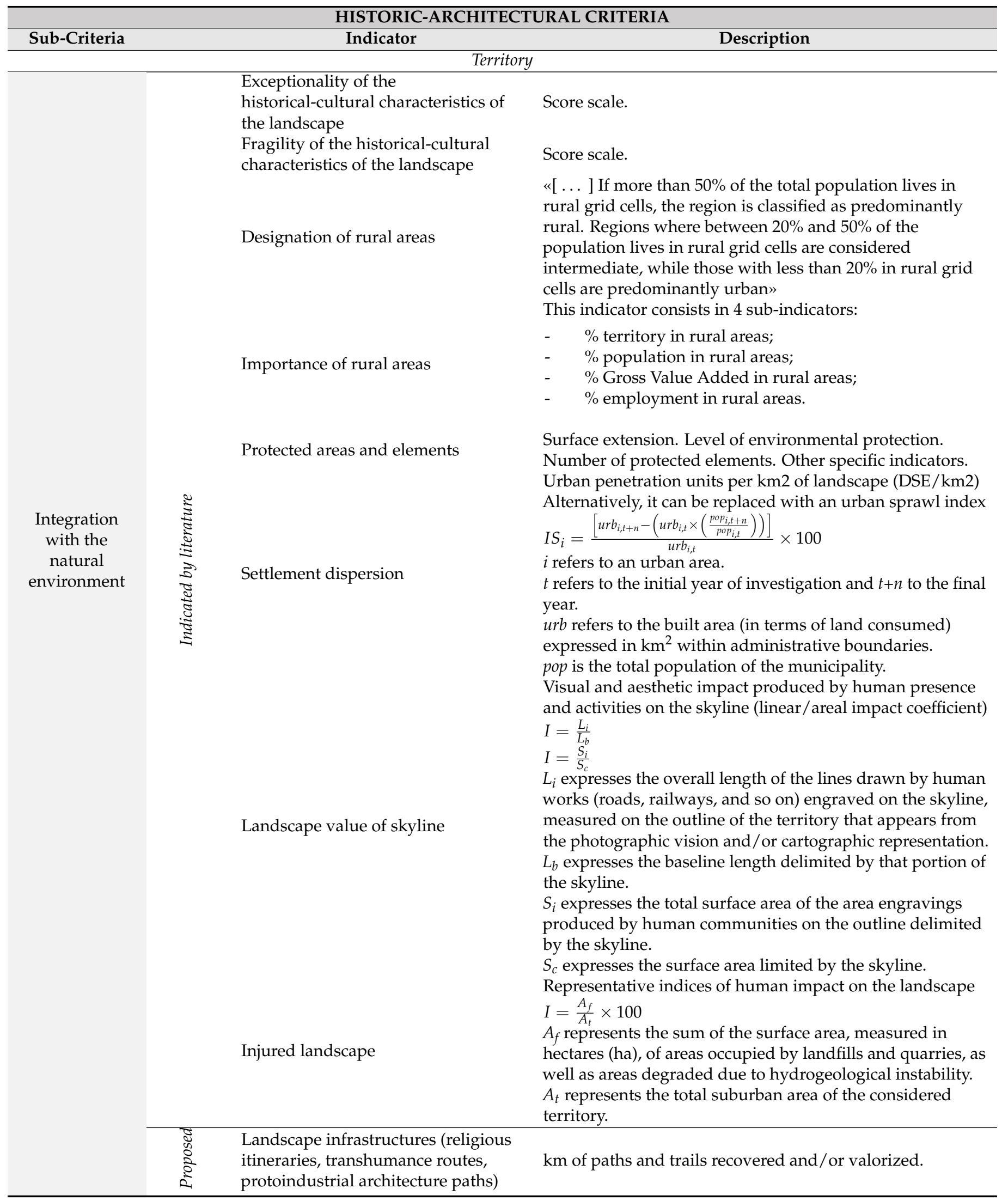


Table A7. Cont.

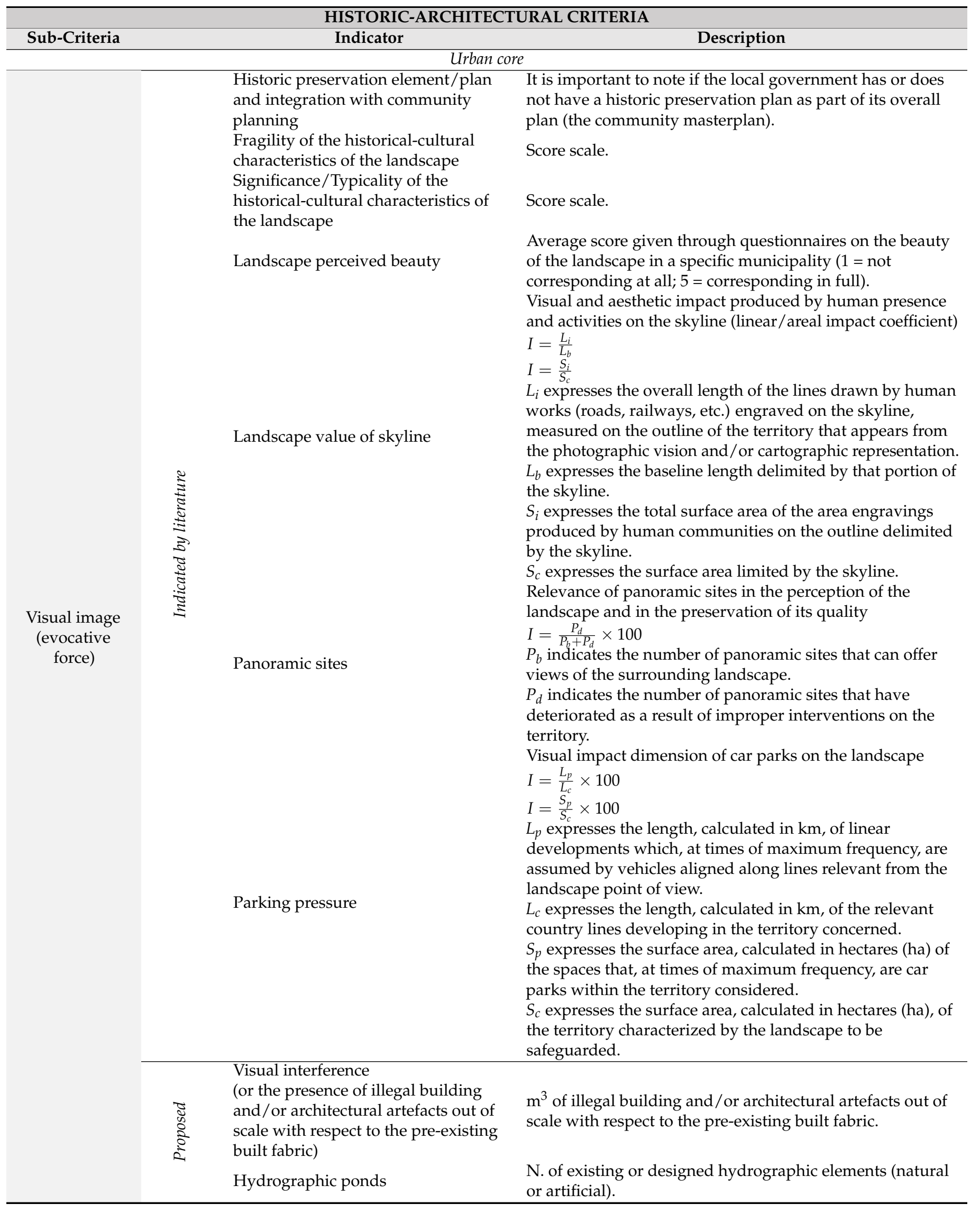


Table A7. Cont.

\begin{tabular}{|c|c|c|c|}
\hline \multicolumn{4}{|c|}{ HISTORIC-ARCHITECTURAL CRITERIA } \\
\hline Sub-Criteria & & Indicator & Description \\
\hline \multirow{2}{*}{$\begin{array}{l}\text { Dialogue } \\
\text { between the } \\
\text { historic urban } \\
\text { fabric and its } \\
\text { context }\end{array}$} & 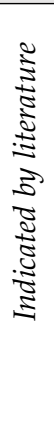 & $\begin{array}{l}\text { Perceived quality of the landscape } \\
\text { around the own home }\end{array}$ & $\begin{array}{l}\text { Share of interviewees who were "not at all satisfied" }(0) \text { to } \\
\text { "very satisfied" (5) with the quality of the landscape around } \\
\text { their home. } \\
\text { Relevance of panoramic sites in the perception of the } \\
\text { landscape and in the preservation of its quality } \\
I=\frac{P_{d}}{P_{b}+P_{d}} \times 100 \\
P_{b} \text { indicates the number of panoramic sites that can offer } \\
\text { views of the surrounding landscape. } \\
P_{d} \text { indicates the number of panoramic sites that have } \\
\text { deteriorated as a result of improper interventions on the } \\
\text { territory. }\end{array}$ \\
\hline & 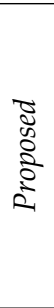 & $\begin{array}{l}\text { Urban morphology (intended as the } \\
\text { aggregation mode of settlements that } \\
\text { define their form. The elements that } \\
\text { structure an urban core are } \\
\text { considered: streets, buildings, open } \\
\text { spaces, green areas) } \\
\text { Level of the relationship between the } \\
\text { small town and its context }\end{array}$ & $\begin{array}{l}\text { How much the project proposal alters the way the } \\
\text { settlement is aggregated (score scale). }\end{array}$ \\
\hline \multirow{8}{*}{$\begin{array}{l}\text { Full/empty } \\
\text { relationship } \\
\text { and equipped } \\
\text { green space } \\
\text { system }\end{array}$} & & $\begin{array}{l}\text { Preservation of relation systems } \\
\text { between assets }\end{array}$ & Score scale. \\
\hline & & Accessibility to open public areas & $\begin{array}{l}\text { Percentage }(\%) \text { of urban area that is located less than } 400 \mathrm{~m} \\
\text { away from an open public space } \\
100 \cdot \frac{\text { population less than } 400 \mathrm{~m} \text { away open public area }}{\text { city population }} \\
100 \cdot \frac{\text { urban area less than } 400 \mathrm{~m} \text { away open public area }}{}\end{array}$ \\
\hline & & $\begin{array}{l}\text { Green, Public space and Heritage } \\
\text { Indicator (GPI) } \\
\text { Public outdoor recreation space }\end{array}$ & $\begin{array}{l}\text { total urban area } \\
\text { Percentage of green or public spaces and local heritage to be } \\
\text { enhanced. } \\
\mathrm{m}^{2} / \text { cap }\end{array}$ \\
\hline & & Green space accessibility & $\begin{array}{l}\% \text { of total population within } 500 \text { metres of public managed } \\
\text { green areas (active and passive). }\end{array}$ \\
\hline & & $\begin{array}{l}\text { The number of green space } \\
\text { reconstruction projects }\end{array}$ & $\begin{array}{l}\text { No. of green space reconstruction projects. YES= score } 5 \text {; } \\
\text { NO= score } 0 . \\
\text { Urban surface area pedestrianized in relation to the quality } \\
\text { of the landscape } \\
I=\frac{P_{e}}{S} \times 100\end{array}$ \\
\hline & & Urban pedestrian areas & $\begin{array}{l}P_{e} \text { indicates the extension, measured in hectares (ha), of } \\
\text { existing pedestrian spaces. } \\
S \text { indicates the extension, measured in hectares (ha), of the } \\
\text { total urban area. }\end{array}$ \\
\hline & & & $\begin{array}{l}\text { It provides an evaluation of the green spaces' function } \\
\text { within the urban landscape }\end{array}$ \\
\hline & & $\begin{array}{l}\text { Valuing of urban public parks and } \\
\text { gardens }\end{array}$ & $\begin{array}{l}I=\frac{S_{a}+S_{n}}{S_{a}} \times 100 \\
S_{a} \text { indicates the area, measured in hectares (ha), of existing } \\
\text { green spaces in the urban environment at the present time. } \\
S_{n} \text { indicates the area, measured in hectares (ha), of the green } \\
\text { spaces that should be realised. }\end{array}$ \\
\hline
\end{tabular}


Table A7. Cont.

\begin{tabular}{|c|c|c|}
\hline \multicolumn{3}{|c|}{ HISTORIC-ARCHITECTURAL CRITERIA } \\
\hline Sub-Criteria & Indicator & Description \\
\hline & $\begin{array}{l}\text { Revitalization of historical urban } \\
\text { spaces }\end{array}$ & $\begin{array}{l}\text { Relationship between the urban spaces that have benefited, } \\
\text { or are benefiting, from architectural recovery and cultural } \\
\text { valorization in a single city, or in a complex of cities, and the } \\
\text { complex of historical urban spaces existing in the urban } \\
\text { context considered } \\
I=\frac{S_{R}+S_{r}}{S_{t}} \times 100 \\
S_{R} \text { expresses the surface area, measured in hectares (ha), of } \\
\text { the city's historical spaces that have benefited from } \\
\text { architectural restoration and cultural heritage valorization. } \\
S_{r} \text { expresses the surface area, measured in hectares (ha), of } \\
\text { historical spaces which, at the time the indicator is } \\
\text { calculated, are subject to architectural restoration and } \\
\text { cultural valorization. } \\
S_{t} \text { expresses the total area, measured in hectares (ha), of the } \\
\text { city's historical spaces taken into account. }\end{array}$ \\
\hline \multicolumn{3}{|c|}{ Building } \\
\hline \multirow[t]{3}{*}{$\begin{array}{l}\text { Formal } \\
\text { relationship }\end{array}$} & $\begin{array}{l}\text { State of preservation of built heritage } \\
\text { with reference to characterizing } \\
\text { elements }\end{array}$ & Score scale. \\
\hline & $\begin{array}{l}\text { Historic preservation element/plan } \\
\text { and integration with community } \\
\text { planning }\end{array}$ & $\begin{array}{l}\text { It is important to note if the local government has or does } \\
\text { not have a historic preservation plan as part of its overall } \\
\text { plan (the community masterplan). }\end{array}$ \\
\hline & Historic fabric & $\begin{array}{l}\text { Measures the amount (\%) of historical fabric in a specific } \\
\text { community. This is done by dating the structures from the } \\
\text { foundation of the settlement to the present day. }\end{array}$ \\
\hline \multirow{4}{*}{$\begin{array}{l}\text { Typological- } \\
\text { distributive } \\
\text { and formal } \\
\text { characteristics } \\
\text { of the building }\end{array}$} & Preservation of the assets & $\begin{array}{l}\text { It is proposed to evaluate this parameter according to the } \\
\text { specificities of the case study (score scale). }\end{array}$ \\
\hline & Use of historical-cultural heritage & Percentage of buildings in use. \\
\hline & Preservation of cultural heritage & Likert's scale. \\
\hline & Ground floor usage & $\%$ of $\mathrm{m}^{2}$ \\
\hline
\end{tabular}

Table A8. The social sub-criteria weights.

\begin{tabular}{|c|c|c|c|c|c|c|}
\hline & & \multicolumn{3}{|c|}{ SUB-CRITERIA } & \multirow[b]{2}{*}{$\begin{array}{l}\text { Sub-criteria } \\
\text { weights }\end{array}$} & \multirow[b]{2}{*}{$\%$} \\
\hline & & $\begin{array}{l}\text { Local traditions } \\
\text { and identities }\end{array}$ & $\begin{array}{c}\text { Secondary } \\
\text { urbanization works }\end{array}$ & $\begin{array}{c}\text { Social assistance } \\
\text { service }\end{array}$ & & \\
\hline \multirow{3}{*}{$\begin{array}{c}\text { SUB- } \\
\text { CRITERIA }\end{array}$} & $\begin{array}{c}\text { Local traditions and } \\
\text { identities }\end{array}$ & 0.40 & 0.40 & 0.40 & 0.40 & $40 \%$ \\
\hline & $\begin{array}{c}\text { Secondary } \\
\text { urbanization works }\end{array}$ & 0.40 & 0.40 & 0.40 & 0.40 & $40 \%$ \\
\hline & $\begin{array}{c}\text { Social assistance } \\
\text { service }\end{array}$ & 0.20 & 0.20 & 0.20 & 0.20 & $20 \%$ \\
\hline
\end{tabular}

Table A9. The economic sub-criteria weights.

\begin{tabular}{|c|c|c|c|c|c|}
\hline & & \multicolumn{2}{|c|}{ SUB-CRITERIA } & \multirow[b]{2}{*}{$\begin{array}{l}\text { Sub-criteria } \\
\text { weights }\end{array}$} & \multirow[b]{2}{*}{$\%$} \\
\hline & & Productive vocations & $\begin{array}{c}\text { Primary } \\
\text { urbanization works }\end{array}$ & & \\
\hline \multirow[b]{2}{*}{ SUB-CRITERIA } & Productive vocations & 0.50 & 0.50 & 0.50 & $50 \%$ \\
\hline & $\begin{array}{c}\text { Primary } \\
\text { urbanization works }\end{array}$ & 0.50 & 0.50 & 0.50 & $50 \%$ \\
\hline
\end{tabular}


Table A10. The environmental sub-criteria weights.

\begin{tabular}{|c|c|c|c|c|c|c|c|}
\hline & & \multicolumn{4}{|c|}{ SUB-CRITERIA } & \multirow[b]{2}{*}{$\begin{array}{c}\text { Sub-criteria } \\
\text { weights }\end{array}$} & \multirow[b]{2}{*}{$\%$} \\
\hline & & $\begin{array}{l}\text { Flora and } \\
\text { fauna }\end{array}$ & $\begin{array}{c}\text { Environmental } \\
\text { quality }\end{array}$ & Green areas & $\begin{array}{c}\text { Bioclimatic } \\
\text { quality }\end{array}$ & & \\
\hline \multirow{4}{*}{$\begin{array}{c}\text { SUB- } \\
\text { CRITERIA }\end{array}$} & $\begin{array}{l}\text { Flora and } \\
\text { fauna }\end{array}$ & 0.14 & 0.17 & 0.14 & 0.13 & 0.145 & $14.5 \%$ \\
\hline & $\begin{array}{c}\text { Environmental } \\
\text { quality }\end{array}$ & 0.28 & 0.33 & 0.28 & 0.37 & 0.32 & $32 \%$ \\
\hline & Green areas & 0.14 & 0.17 & 0.14 & 0.13 & 0.145 & $14.5 \%$ \\
\hline & $\begin{array}{c}\text { Bioclimatic } \\
\text { quality }\end{array}$ & 0.43 & 0.33 & 0.43 & 0.37 & 0.39 & $39 \%$ \\
\hline
\end{tabular}

Table A11. Social criteria: correspondence between sub-criteria and assessment indicators for the Riccia's Well-being Village project.

\begin{tabular}{ccl}
\hline SUB-CRITERIA & SOCIAL CRITERIA \\
\hline Local traditions and identities & $\bullet$ & \multicolumn{1}{c}{ SELECTED INDICATOR(S) number of cultural events } \\
\hline Secondary urbanization works & $\bullet \begin{array}{l}\text { Access to local/neighbourhood services within a short } \\
\text { distance }\end{array}$ \\
\hline Social assistance service & $\bullet$ & The number of assistance centers \\
\hline
\end{tabular}

Table A12. Economic criteria: correspondence between sub-criteria and assessment indicators for the Riccia's Well-being Village project.

\begin{tabular}{|c|c|}
\hline \multicolumn{2}{|c|}{ ECONOMIC CRITERIA } \\
\hline SUB-CRITERIA & SELECTED INDICATOR(S) \\
\hline Productive vocations & $\begin{array}{ll}\text { - } & \text { Agricultural land use } \\
\text { - } & \text { Skills recovery }\end{array}$ \\
\hline $\begin{array}{c}\text { Primary urbanization } \\
\text { works }\end{array}$ & $\begin{array}{l}\text { - Quality of the street and sidewalks cover } \\
\text { Percentage of houses with } \\
\text { communications (including electricity, } \\
\text { water, sewage, gas, heating, internet, } \\
\text { phone lines) } \\
\text { - The number of public Wi-Fi places }\end{array}$ \\
\hline
\end{tabular}

Table A13. Environmental criteria: correspondence between sub-criteria and assessment indicators for the Riccia's Well-being Village project.

\begin{tabular}{rll}
\hline \multicolumn{2}{c}{ ENVIRONMENTAL CRITERIA } \\
\hline SUB-CRITERIA & \multicolumn{1}{c}{ SELECTED INDICATOR(S) } \\
\hline Flora and fauna & $\bullet$ & Urban land take \\
\hline Environmental quality & $\bullet \quad \mathrm{CO}_{2}$ emissions \\
Green areas & $\bullet$ & Presence of treatment systems \\
\hline Bioclimatic quality & $\bullet$ & Green space \\
\hline
\end{tabular}


Table A14. Historic-architectural criteria: correspondence between sub-criteria and assessment indicators for the Riccia's Well-being Village project.

\begin{tabular}{|c|c|}
\hline \multicolumn{2}{|c|}{ HISTORIC-ARCHITECTURAL CRITERIA } \\
\hline SUB-CRITERIA & SELECTED INDICATOR(S) \\
\hline Integration with the natural environment & $\begin{array}{l}\text { - Exceptionality of the historical-cultural characteristics of } \\
\text { the landscape }\end{array}$ \\
\hline Visual image & - Landscape value of skyline \\
\hline Dialogue between the historic urban fabric and its context & - $\quad$ Panoramic sites \\
\hline Empty/Full relationship and equipped green space system & $\begin{array}{l}\text { - } \quad \text { Preservation of relation systems between assets } \\
\text { - The number of green space reconstruction projects }\end{array}$ \\
\hline Formal relationship between building and urban core & $\begin{array}{l}\text { - State of preservation of built heritage with reference to } \\
\text { characterizing elements }\end{array}$ \\
\hline Typological-distributive and formal characteristics of the building & $\begin{array}{l}\text { - } \quad \text { Preservation of the assets } \\
\text { - } \quad \text { Use of historical-cultural heritage }\end{array}$ \\
\hline
\end{tabular}

Table A15. Weighted scores for social sub-criteria.

\begin{tabular}{|c|c|c|c|c|c|c|}
\hline Sub-Criteria & $\begin{array}{l}\text { Weight } \\
\text { (W) }\end{array}$ & $\begin{array}{l}\text { Assessment } \\
\text { Indicator }\end{array}$ & $\begin{array}{l}\text { Score } \\
(S)\end{array}$ & $\begin{array}{l}\text { Weighted } \\
\text { Score }\left(S_{w}\right)\end{array}$ & $\begin{array}{c}\text { Maximum } \\
\text { Weighted Score } \\
\left(S_{\max }\right)\end{array}$ & $\begin{array}{c}\% S_{w} \text { Compared to } \\
S_{\max }\end{array}$ \\
\hline $\begin{array}{l}\text { Local traditions } \\
\text { and identities }\end{array}$ & $40 \%$ & $\begin{array}{l}\text { The number of } \\
\text { cultural events }\end{array}$ & 4 & 1.6 & 2 & $\begin{array}{c}80 \%>60 \% \\
\text { ACCEPTED }\end{array}$ \\
\hline $\begin{array}{l}\text { Secondary } \\
\text { urbanization } \\
\text { works }\end{array}$ & $40 \%$ & $\begin{array}{l}\text { Access to lo- } \\
\text { cal/neighbourhood } \\
\text { services within } \\
\text { a short distance }\end{array}$ & 4 & 1.6 & 2 & $\begin{array}{c}80 \%>60 \% \\
\text { ACCEPTED }\end{array}$ \\
\hline $\begin{array}{c}\text { Social assistance } \\
\text { service }\end{array}$ & $20 \%$ & $\begin{array}{l}\text { - The number of } \\
\text { assistance } \\
\text { centers }\end{array}$ & 5 & 1 & 1 & $\begin{array}{l}100 \%>60 \% \\
\text { ACCEPTED }\end{array}$ \\
\hline
\end{tabular}


Table A16. Weighted scores for economic sub-criteria.

\begin{tabular}{|c|c|c|c|c|c|c|}
\hline Sub-Criteria & $\begin{array}{c}\text { Weight } \\
(W)\end{array}$ & Assessment Indicator & $\begin{array}{l}\text { Score } \\
(S)\end{array}$ & $\begin{array}{l}\text { Weighted Score } \\
\qquad\left(S_{w}\right)\end{array}$ & $\begin{array}{c}\text { Maximum } \\
\text { Weighted Score } \\
\left(S_{\max }\right) \\
\end{array}$ & $\begin{array}{c}\% S_{w} \text { Compared } \\
\text { to } S_{\max }\end{array}$ \\
\hline $\begin{array}{l}\text { Productive } \\
\text { vocations }\end{array}$ & $50 \%$ & $\begin{array}{l}\text { - } \begin{array}{l}\text { Agricultural land } \\
\text { use }\end{array} \\
\text { - } \quad \text { Skills recovery }\end{array}$ & 4 & 1.25 & 2.5 & $\begin{array}{c}50 \%<60 \% \\
\text { NOT } \\
\text { ACCEPTED }\end{array}$ \\
\hline \multirow{3}{*}{$\begin{array}{c}\text { Primary } \\
\text { urbanization } \\
\text { works }\end{array}$} & \multirow{3}{*}{$50 \%$} & $\begin{array}{l}\text { Quality of the } \\
\text { street and } \\
\text { sidewalks cover }\end{array}$ & 5 & \multirow{3}{*}{2.5} & \multirow{3}{*}{2.5} & \multirow{3}{*}{$\begin{array}{l}100 \%>60 \% \\
\text { ACCEPTED }\end{array}$} \\
\hline & & 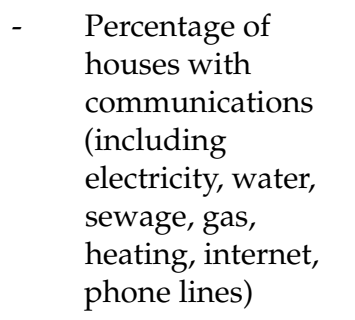 & 5 & & & \\
\hline & & $\begin{array}{l}\text { The number of } \\
\text { public Wi-Fi places }\end{array}$ & 5 & & & \\
\hline
\end{tabular}

Table A17. Weighted scores for environmental sub-criteria.

\begin{tabular}{|c|c|c|c|c|c|c|}
\hline Sub-Criteria & $\begin{array}{l}\text { Weight } \\
\text { (W) }\end{array}$ & $\begin{array}{l}\text { Assessment } \\
\text { Indicator }\end{array}$ & $\begin{array}{l}\text { Score } \\
(S)\end{array}$ & $\begin{array}{l}\text { Weighted Score } \\
\qquad\left(S_{w}\right)\end{array}$ & $\begin{array}{c}\text { Maximum } \\
\text { Weighted Score } \\
\left(S_{\max }\right)\end{array}$ & $\begin{array}{c}\% S_{w} \\
\text { Compared to } \\
S_{\max }\end{array}$ \\
\hline \multicolumn{7}{|c|}{ Territory } \\
\hline Flora and fauna & $14.5 \%$ & $\begin{array}{l}\text { Urban land } \\
\text { take }\end{array}$ & 5 & 0.725 & 0.725 & $\begin{array}{l}100 \%>60 \% \\
\text { ACCEPTED }\end{array}$ \\
\hline \multirow[t]{2}{*}{$\begin{array}{l}\text { Environmental } \\
\text { quality }\end{array}$} & $32 \%$ & $\begin{array}{ll}- & \mathrm{CO}_{2} \\
& \text { emissions }\end{array}$ & 5 & 1.6 & 1.6 & $\begin{array}{l}100 \%>60 \% \\
\text { ACCEPTED }\end{array}$ \\
\hline & & $\begin{array}{l}\text { - Presence of } \\
\text { treatment } \\
\text { systems }\end{array}$ & 5 & & & \\
\hline \multicolumn{7}{|c|}{ Urban core } \\
\hline Green areas & $14.5 \%$ & Green space & 5 & 0.725 & 0.725 & $\begin{array}{r}100 \%>60 \% \\
\text { ACCEPTED }\end{array}$ \\
\hline \multicolumn{7}{|c|}{ Building } \\
\hline $\begin{array}{l}\text { Bioclimatic } \\
\text { quality }\end{array}$ & $39 \%$ & Energy class & 5 & 1.95 & 1.95 & $\begin{array}{r}100 \%>60 \% \\
\text { ACCEPTED }\end{array}$ \\
\hline
\end{tabular}


Table A18. Weighted scores for historic-architectural sub-criteria.

\begin{tabular}{|c|c|c|c|c|c|c|}
\hline Sub-Criteria & $\begin{array}{l}\text { Weight } \\
(W)\end{array}$ & $\begin{array}{l}\text { Assessment } \\
\text { Indicator }\end{array}$ & $\begin{array}{l}\text { Score } \\
(S)\end{array}$ & $\begin{array}{l}\text { Weighted Score } \\
\qquad\left(S_{w}\right)\end{array}$ & $\begin{array}{c}\text { Maximum } \\
\text { Weighted Score } \\
\left(S_{\max }\right) \\
\end{array}$ & $\begin{array}{c}\% S_{w} \\
\text { Compared to } \\
S_{\max }\end{array}$ \\
\hline \multicolumn{7}{|c|}{ Territory } \\
\hline $\begin{array}{l}\text { Integration with } \\
\text { the natural } \\
\text { environment }\end{array}$ & $16.66 \%$ & $\begin{array}{l}\text { Exceptionality } \\
\text { of the historical- } \\
\text { cultural } \\
\text { characteristics } \\
\text { of the } \\
\text { landscape }\end{array}$ & 5 & 0.83 & 0.83 & $\begin{array}{l}100 \%>60 \% \\
\text { ACCEPTED }\end{array}$ \\
\hline \multicolumn{7}{|c|}{ Urban core } \\
\hline Visual image & $16.66 \%$ & $\begin{array}{l}\text { - Landscape } \\
\text { value of skyline }\end{array}$ & 4 & 0.67 & 0.83 & $\begin{array}{c}80.72 \%>60 \% \\
\text { ACCEPTED }\end{array}$ \\
\hline $\begin{array}{l}\text { Dialogue between } \\
\text { the historic urban } \\
\text { fabric and its } \\
\text { context }\end{array}$ & $16.66 \%$ & Panoramic sites & 5 & 0.83 & 0.83 & $\begin{array}{l}100 \%>60 \% \\
\text { ACCEPTED }\end{array}$ \\
\hline $\begin{array}{l}\text { Empty/Full } \\
\text { relationship and } \\
\text { equipped green } \\
\text { space system }\end{array}$ & $16.66 \%$ & $\begin{array}{l}\text { - } \quad \begin{array}{l}\text { Preservation of } \\
\text { relation } \\
\text { systems } \\
\text { between assets }\end{array} \\
\text { - } \begin{array}{l}\text { The number of } \\
\text { green space } \\
\text { reconstruction } \\
\text { projects }\end{array}\end{array}$ & 4 & 0.75 & 0.83 & $\begin{array}{l}90.36 \%>60 \% \\
\text { ACCEPTED }\end{array}$ \\
\hline \multicolumn{7}{|c|}{ Building } \\
\hline $\begin{array}{c}\text { Formal relationship } \\
\text { between building } \\
\text { and urban core }\end{array}$ & $16.66 \%$ & $\begin{array}{l}\text { State of } \\
\text { preservation of } \\
\text { built heritage } \\
\text { with reference } \\
\text { to } \\
\text { characterizing } \\
\text { elements }\end{array}$ & 5 & 0.83 & 0.83 & $\begin{array}{l}100 \%>60 \% \\
\text { ACCEPTED }\end{array}$ \\
\hline $\begin{array}{c}\text { Typological- } \\
\text { distributive and } \\
\text { formal } \\
\text { characteristics of } \\
\text { the building }\end{array}$ & $16.66 \%$ & $\begin{array}{l}\text { Use of } \\
\text { historical- } \\
\text { cultural } \\
\text { heritage }\end{array}$ & 1 & 0.42 & 0.83 & $\begin{array}{c}50.60 \%<60 \% \\
\text { NOT } \\
\text { ACCEPTED }\end{array}$ \\
\hline
\end{tabular}

\section{References}

1. Nesticò, A.; D’Andria, E.; Fiore, P. Centri Minori e Strategie di Intervento. In I Centri Minori da Problema a Risorsa. Strategie Sostenibili per la Valorizzazione del Patrimonio Edilizio, Paesaggistico e Culturale Nelle Aree Interne, 1st ed.; Fiore, P., D'Andria, E., Eds.; FrancoAngeli Editore: Milan, Italy, 2019; p. 1399.

2. De Rossi, A. (Ed.) Riabitare l'Italia. Le Aree Interne tra Abbadoni e Riconquiste, 1st ed.; Donzelli Editore: Rome, Italy, $2018 ;$ p. 5.

3. Visvizi, A.; Lytras, M.; Mudri, G. Smart Villages in the EU and Beyond, 1st ed.; Emerald Group Pub Ltd: Bingley, UK, 2019. 
4. Patnaik, S.; Sen, S.; Mahmoud, M. (Eds.) Smart Village Technology, 1st ed.; Springer: Cham, Switzerland, 2020.

5. Fiore, P.; Blandón-González, B.; D’Andria, E. Smart Villages for the Sustainable Regeneration of Small Municipalities. In Modernization and Globalization: Challenges and Opportunities in Architecture, Urbanism, Cultural Heritage, 1st ed.; Nepravishta, F., Maliqari, A., Eds.; Flesh: Tiranë, Albania, 2019; pp. 840-847.

6. Servillo, L.; Atkinson, R.; Smith, I.; Russo, A.; Sýkora, L.; Demazière, C.; Hamdouche, A. Town, Small and Medium Sized Towns in Their Functional Territorial Context, 1st ed.; Draft Final Report; Espon: Luxembourg, 2014.

7. Copus, A.; Kahila, P.; Fritsch, M.; Dax, T.; Kovács, K.; Tagai, G.; Weber, R.; Grunfelfer, J.; Löfving, L.; Moodie, J.; et al. Escape European Shrinking Rural Areas: Challenges, Actions and Perspectives for Territorial Governance, 1st ed.; Final Report; Espon: Luxembourg, 2020.

8. Birnbaum, J.; Fox, L.; Hawken, P. Sustainable Revolution: Permaculture in Ecovillages, Urban Farms, and Communities Worldwide, 1st ed.; North Atlantic Books: Berkeley, CA, USA, 2014.

9. Litfin, K. Ecovillages: Lessons for Sustainable Community, 1st ed.; Polity Pr: Cambridge, UK, 2013.

10. Guidotti, F. Ecovillaggi e Cohousing, 1st ed.; Terra Nuova Edizioni: Florence, Italy, 2015.

11. ANCE. I Borghi d'Italia Dalla Visione Alla Rigenerazione, 1st ed.; ANCE: Rome, Italy, 2017; p. 11.

12. Del Molino, S. La Spagna Vuota, 1st ed.; Sellerio Editore: Palermo, Italy, 2019.

13. Paolella, A. Il Riuso dei Borghi Abbandonati. Esperienze di Comunità, 1st ed.; Pellegrini Editore: Cosenza, Italy, 2019.

14. Berizzi, C.; Rocchelli, L. Borghi Rinati. Paesaggi Abbandonati e Interventi di Rigenerazione, 1st ed.; Il Poligrafo: Padua, Italy, 2019.

15. Ricci, M.; Battisti, A.; Monardo, B. (Eds.) I Borghi della Salute. Healthy Ageing per Nuovi Progetti di Territorio, 1st ed.; Alinea Editrice: Florence, Italy, 2014.

16. Droli, M.; Dall'Ara, G. Ripartire Dalla Bellezza. Gestione e Marketing Delle Opportunità D'innovazione Nell'albergo Diffuso nei Centri Storici e Nelle Aree Rurali, 1st ed.; CLEUP: Padua, Italy, 2012.

17. D'Andria, E.; Fiore, P.; Nesticò, A. Historical-Architectural Components in the Projects Multi-criteria Analysis for the Valorization of Small Towns. In New Metropolitan Perspectives, 1st ed.; Bevilaqua, C., Calabrò, F., Della Spina, L., Eds.; Springer: Cham, Switzerland, 2021; Volume 178, pp. 652-662. [CrossRef]

18. Coletta, T. de la source I Centri Storici Minori Abbandonati Della Campania. Conservazione, Recupero e Valorizzazione; Edizioni Scientifiche Italiane: Naples, Italy, 2010; p. 77.

19. Figueira, J.; Greco, S.; Ehrgott, M. Multiple Criteria Decision Analysis: State of the Art Surveys, 2nd ed.; Springer: New York, NY, USA, 2016.

20. Nesticò, A.; Somma, P. Comparative Analysis of Multi-Criteria Methods for the Enhancement of Historical Buildings. Sustainability 2019, 11, 4526. [CrossRef]

21. Ishizaka, A.; Nemery, P. Multi-Criteria Decision Analysis: Methods and Software, 1st ed.; John Wiley \& Sons: Chichester, UK, 2013.

22. Roy, B. Méthodologie Multicritére d'Aide à la Décision, 1st ed.; Economica: Paris, France, 1985.

23. Guitoni, A.; Martel, J.M. Tentative guidelines to help choosing an appropriate MCDA method. Eur. J. Oper. Res. 1998, 109, 501-521. [CrossRef]

24. Vincke, P. L'aide Multicritère à la Décision, 1st ed.; Université de Bruxelles: Bruxelles, Belgium, 1989.

25. Colson, G.; De Bruyn, C. Models and Methods in Multiple Criteria Decision Making, 1st ed.; Pergamon Press: Oxford, UK, 1989; Volume 23.

26. Fishburn, P.C. A Survey of Multiattribute/Multicriterion Evaluation Theories. In Multiple Criteria Problem Solving, 1st ed.; Zionts, S., Ed.; Springer: Heidelberg, Germany, 1978; pp. 181-224.

27. Roy, B.; Bouyssou, D. Aide Multicritère à la Décision: Methodes et Cas, 1st ed.; Economica: Paris, France, 1993.

28. Keeney, R.L.; Raiffa, H. Decisions with Multiple Objectives: Preferences and Value Trade-Offs, 1st ed.; Cambridge University Press: Cambridge, UK, 1993.

29. De Montis, A. Analisi Multicriteri e Valutazione per la Pianificazione Territoriale, 1st ed.; CUEC Editrice: Cagliari, Italy, 2001.

30. Mardani, A.; Jusoh, A.; Nor, K.; Khalifah, Z.; Zakwan, N.; Valipour, A. Multiple criteria decision-making techniques and their applications-A review of the literature from 2000 to 2014. Econ. Res. Ekon. Istraživanja 2015, 28, 516-571. [CrossRef]

31. Lanza, A. Lo Sviluppo Sostenibile, 4th ed.; Il Mulino: Bologna, Italy, 2006.

32. Walker, J.; Pekmezovic, A.; Walker, G. Sustainable Development Goals: Harnessing Business to Achieve the SDGs Through Finance, Technology and Law Reform, 1st ed.; John Wiley \& Sons Inc.: Hoboken, NJ, USA, 2019.

33. Clementi, C.; Giordani, M.; Poponessi, P. L'Italia dei Borghi. Strategie di Promozione e Comunicazione, 1st ed.; Historica Edizioni: Cesena, Italy, 2017.

34. Nesticò, A.; De Mare, G. Government Tools for Urban Regeneration: The Cities Plan in Italy. A Critical Analysis of the Results and the Proposed Alternative. In International Conference on Computational Science and Its Applications; Part II, LNCS, 2014; Murgante, B., Misra, S., Rocha, A.M.A.C., Torre, C., Rocha, J.G., Falcão, M.I., Taniar, D., Apduhan, B.O., Gervasi, O., Eds.; Springer: Cham, Switzerland, 2014; Volume 8580, pp. 547-562. [CrossRef]

35. Bottero, M.; Lami, I.; Lombardi, P. Analytic Network Process. La Valutazione di Scenari di Trasformazione Urbana e Territoriale, 1st ed.; Alinea Editrice: Florence, Italy, 2008.

36. Fusco Girard, L.; Nijkamp, P. Le Valutazioni per lo Sviluppo Sostenibile Della Città e del Territorio, 3rd ed.; FrancoAngeli: Milan, Italy, 2000.

37. Carver, N.F. Borghi Collinari Italiani, 1st ed.; Clean Edizioni: Naples, Italy, 2017. 
38. Nesticò, A.; D'Andria, E.; Fiore, P. Small towns and valorization projects. Criteria and indicators for economic evaluation. Valori Valutazioni 2020, 25, 3-10.

39. Romana Stabile, F.; Zampilli, M.; Cortesi, C. Centri Storici Minori. Progetti per il Recupero Della Bellezza, 1st ed.; Gangemi: Rome, Italy, 2009.

40. Briatore, S. Valorizzazione dei Centri Storici Minori. Strategie di Intervento, 1st ed.; Diabasis Edizioni: Reggio Emilia, Italy, 2011.

41. Cirasa, M. Recupero Degli Spazi Aperti di Relazione nei Centri Storici Minori. Aspetti Bioclimatici e Innovazione Tecnologica, 1st ed.; Gangemi: Rome, Italy, 2011.

42. Fiore, P. La Valorizzazione dei Centri Minori. Strategie per una Conservazione Integrata Dell'antico Borgo di Aterrana, 1st ed.; CUES: Fisciano, Italy, 2007.

43. Mega, V.; Pedersen, J. Urban Sustainability Indicators, 1st ed.; Office for Official Publications of the European Communities: Luxembourg, 1998.

44. Mameli, F.; Marletto, G. A Selection of Indicators for Monitoring Sustainable Urban Mobility Policies. In Trasporti, Ambiente e Territorio. La Ricerca di un Nuovo Equlibrio, 1st ed.; Marletto, G., Musso, E., Eds.; FrancoAngeli Editore: Milan, Italy, 2010; pp. 167-174.

45. Vallega, A. Indicatori per il Paesaggio, 1st ed.; FrancoAngeli: Milan, Italy, 2009.

46. Minx, J.; Creutzig, F.; Ziegler, T.; Owen, A. Developing a Pragmatic Approach to Assess Urban Metabolism in Europe. A Report to the European Environment Agency, 1st ed.; Technische Universität Berlin; Stockholm Environment Institute; Climatecon: Berlin, Germany, 2011.

47. Directorate-General Environment, European Commission. Science for Environment Policy, In-Depth Report: Indicators for Sustainable Cities; EEA Urban Metabolism Framework; Issue 12; European Commission: Brussels, Belgium, 2018; p. 13.

48. United Nations Economic Commission for Europe. Transport for Sustainable Development in the ECE Region, 1st ed.; UNECE Transport Division: Geneva, Switzerland, 2011.

49. Volpiano, M. Indicators for the Assessment of Historic Landscape Features. In Landscape Indicators, 1st ed.; Cassatella, C., Peano, A., Eds.; Springer: Heidelberg, Germany, 2011; pp. 77-104.

50. Directorate-General for Agriculture and Rural Development. Rural Development in the European Union Statistical and Economic Information Report 2013, 1st ed.; European Commission: Brussels, Belgium, 2013.

51. European Spatial Planning Observation Network (ESPON). KITCASP. Key Indicators for Territorial Cohesion and Spatial Planning. Part A, Executive Summary, 1st ed.; European Commission: Brussels, Belgium, 2013.

52. Phillips, R.G.; Stein, J.M. An Indicator Framework for Linking Historic Preservation and Community Economic Development. Soc. Indic. Res. 2013, 113, 1-15. [CrossRef]

53. Valtenbergs, V.; González, A.; Piziks, R. Selecting Indicators for Sustainable Development of Small Towns: The Case of Valmiera Municipality. Procedia Comput. Sci. Spec. Issue ICTE Reg. Dev. 2013, 26, 21-32.

54. European Environment Agency (EEA). Core Set of Indicators (CSI). In Digest of EEA Indicators 2014, 1st ed.; European Environment Agency: Luxembourg, 2014; Volume 8, pp. 28-31.

55. UN-Habitat. Measurement of City Prosperity. Methodology and Metadata, 1st ed.; UN-Habitat: Nairobi, Kenya, 2016; pp. 20-128.

56. Bosch, P.; Jongeneel, S.; Rovers, V.; Neumann, H.-M.; Airaksinen, M.; Huovila, A. Citykeys List of City Indicators, 1st ed.; CITYkeys: Brussels, Belgium, 2017.

57. Neely, A.; Adams, C.; Kennerley, M. The Performance Prism; Financial Times/Prentice Hall: Hoboken, NJ, USA, 2002.

58. Nesticò, A.; Maselli, G. Sustainability indicators for the economic evaluation of tourism investments on islands. J. Clean. Prod. 2020, 248, 119217-119227. [CrossRef]

59. Nesticò, A.; Fiore, P.; D'Andria, E. Enhancement of Small Towns in Inland Areas. A Novel Indicators Dataset to Evaluate Sustainable Plans. Sustainability 2020, 12, 6359. [CrossRef] 